\title{
Doi: https://doi.org/10.47879/ed.ep.2020025
}

Letícia Manhães Cordeiro

TFG em Arquitetura

Professor: Adriano Arpad Moreira Gomes

Orientador: Bruno Matos de Farias

Revitalização da Praça do Suspiro 


\section{REVITALIZAÇÃO}

A revitalização é um processo de planejamento estratégico, capaz de reconhecer, manter e induzir valores de forma cumulativa. Assim, intervém de médio a longo prazo promovendo relações entre o lugar, atividades e pessoas, como consequência, melhora a qualidade do meio urbano e das condições socioeconômicas (BARRETO \& GILSON, 2013). 


\section{Localização}
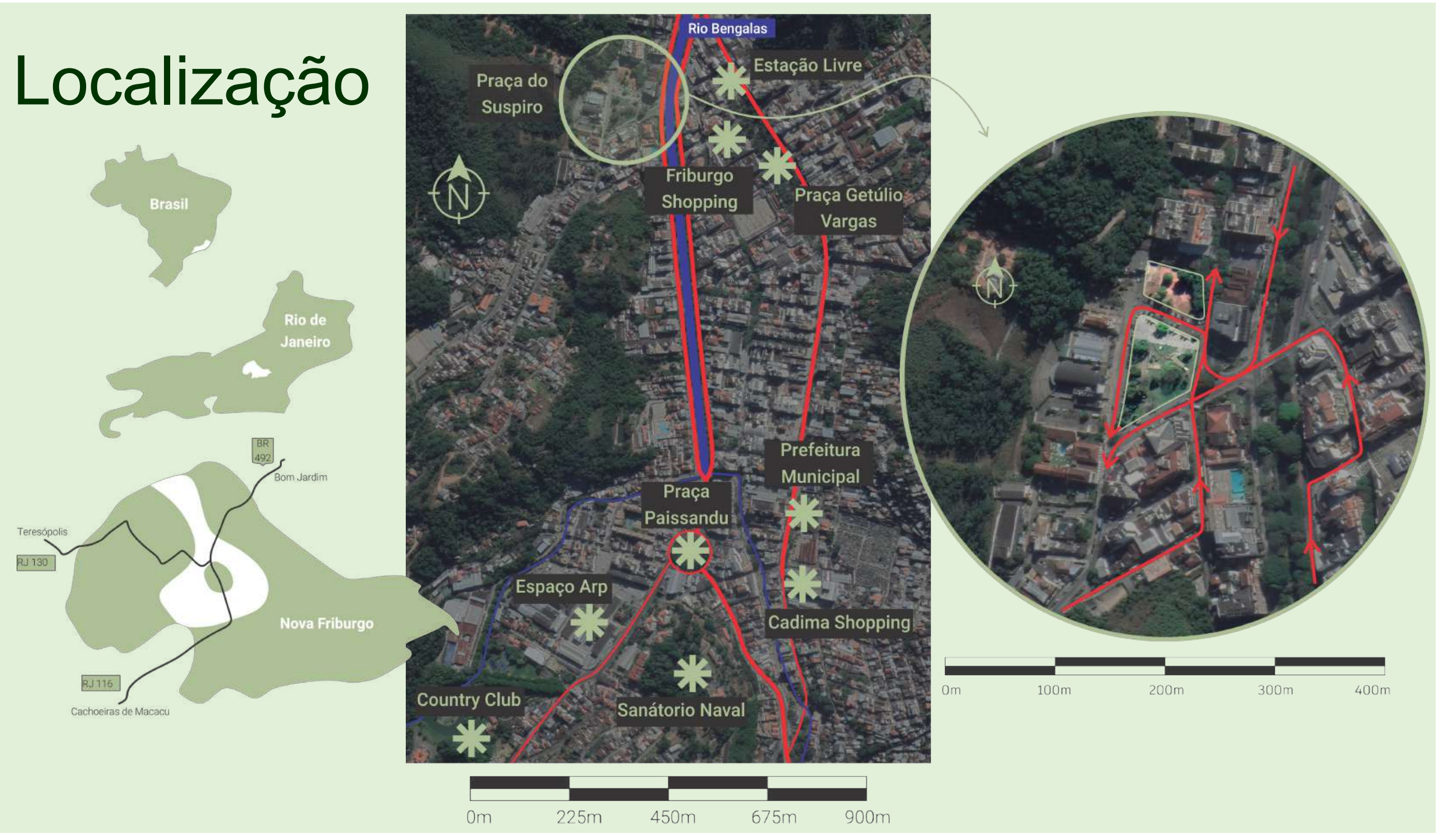
Praças e Centros Culturais

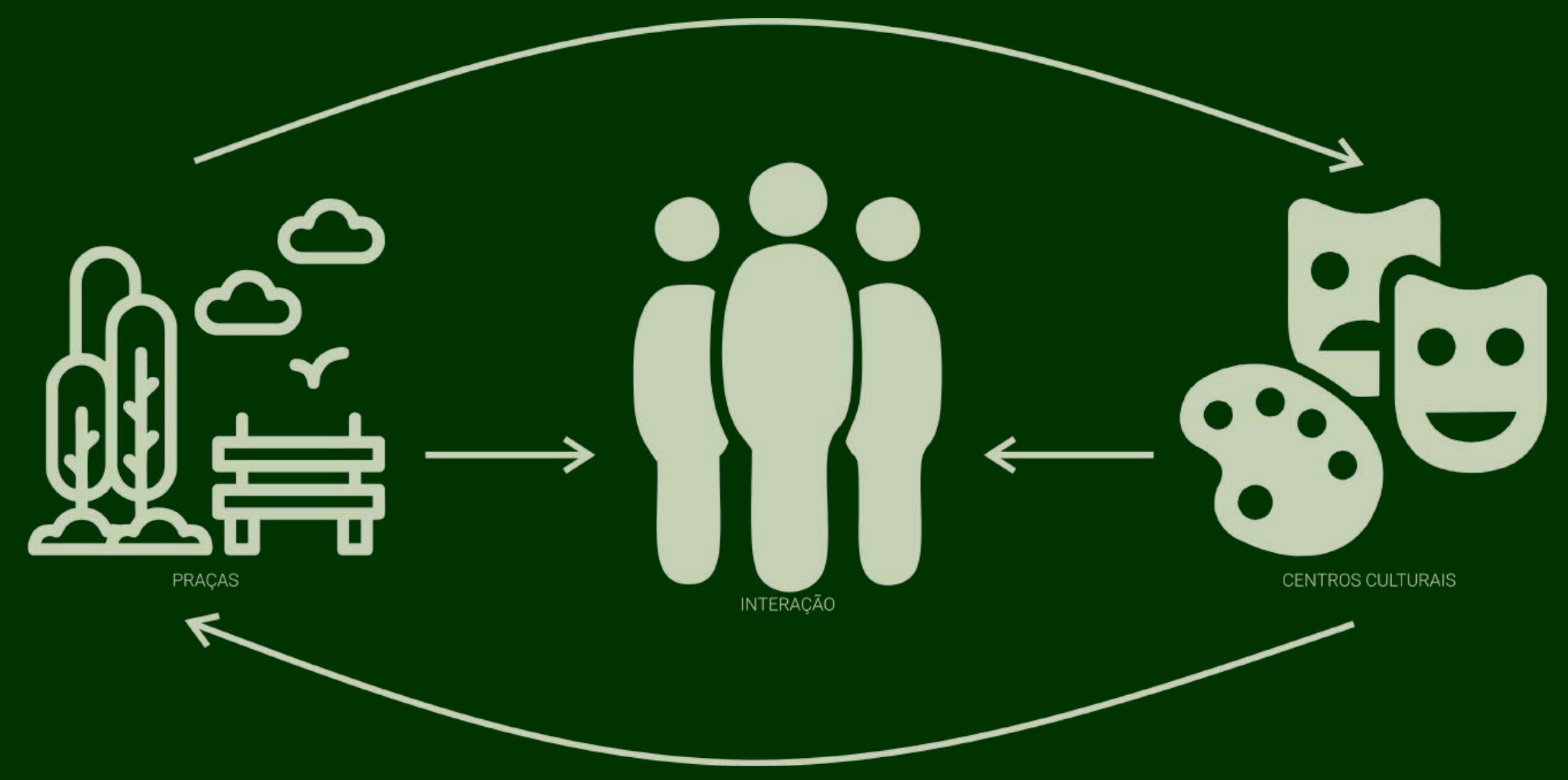




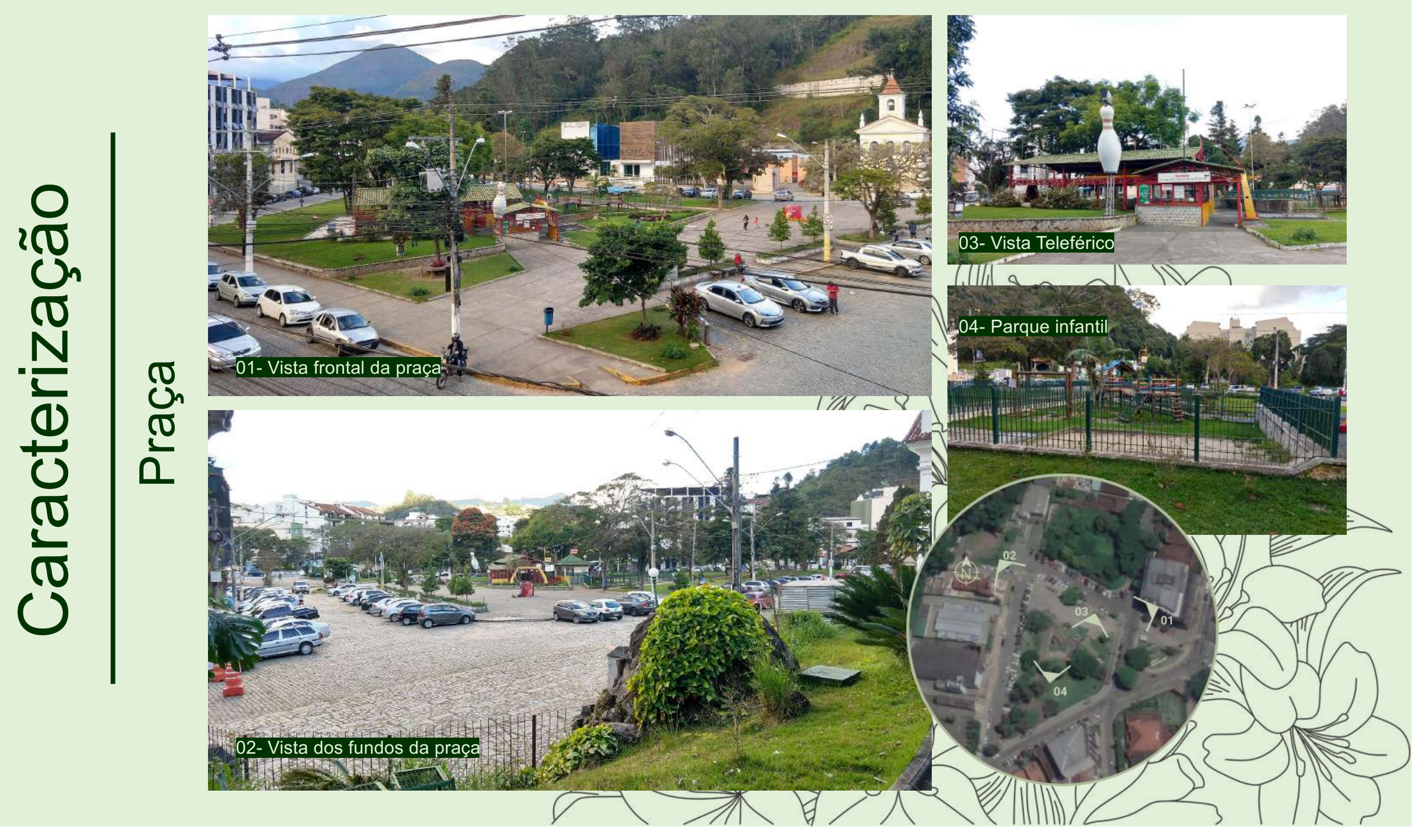




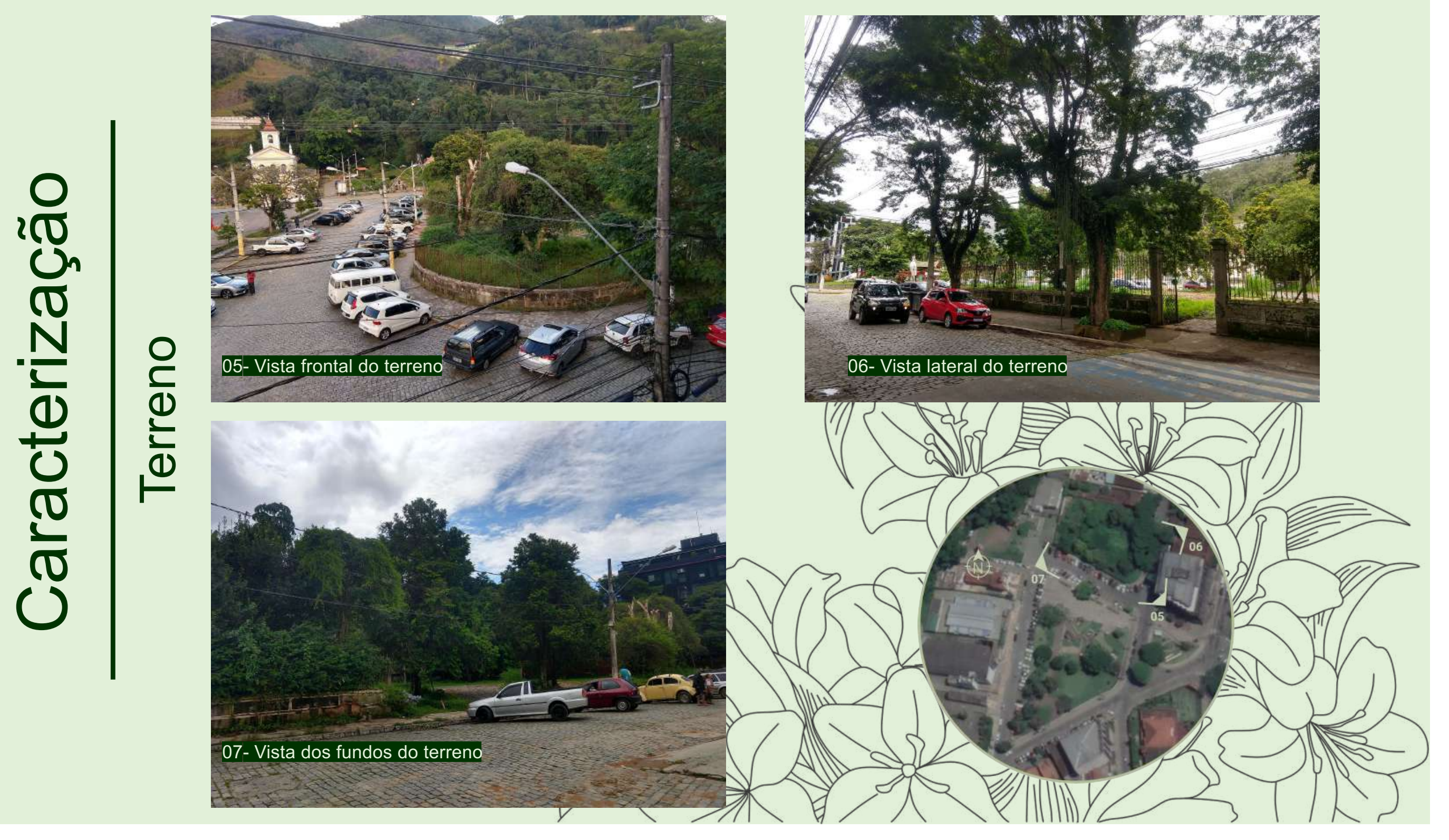




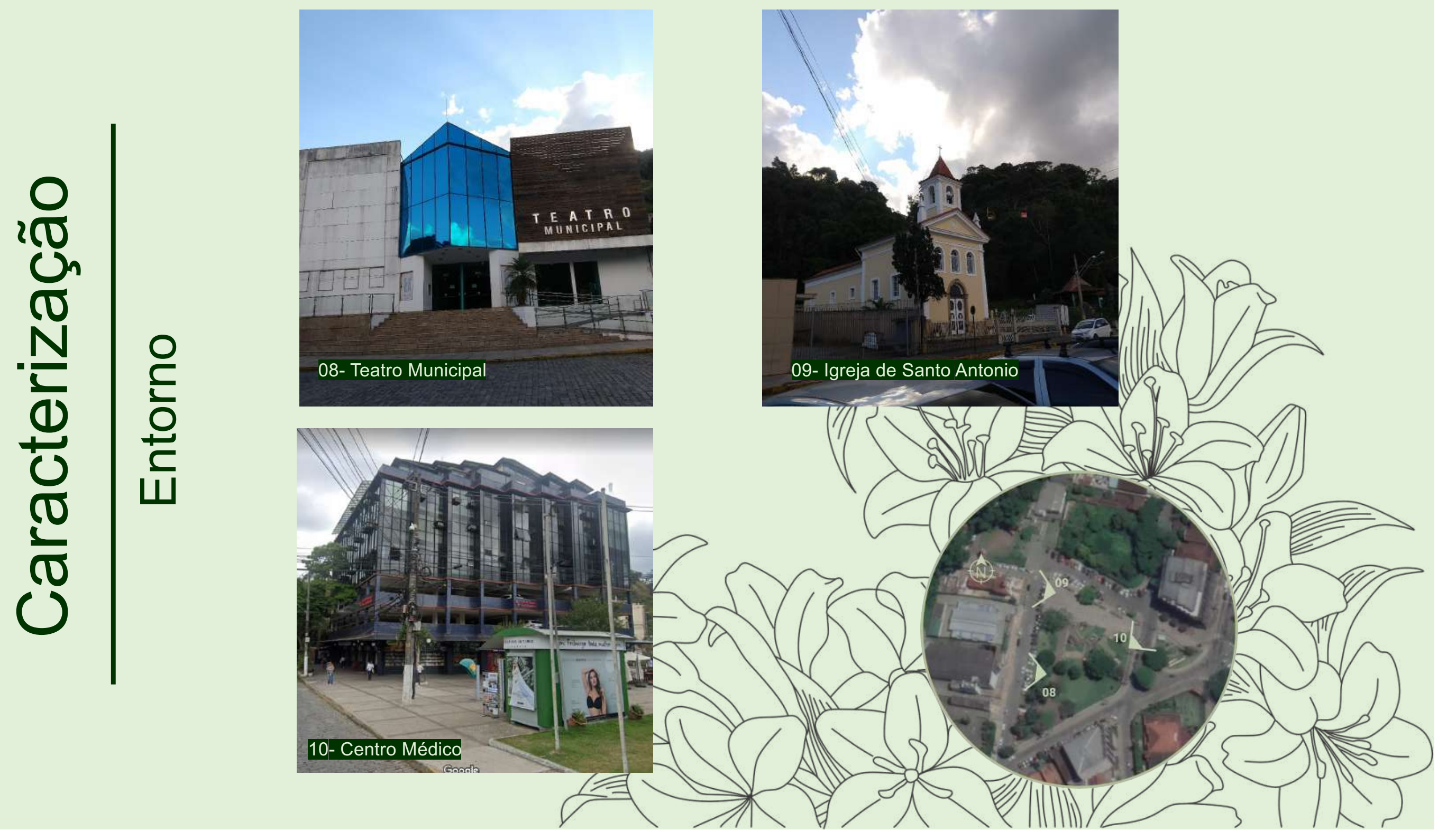




\section{Histórico}

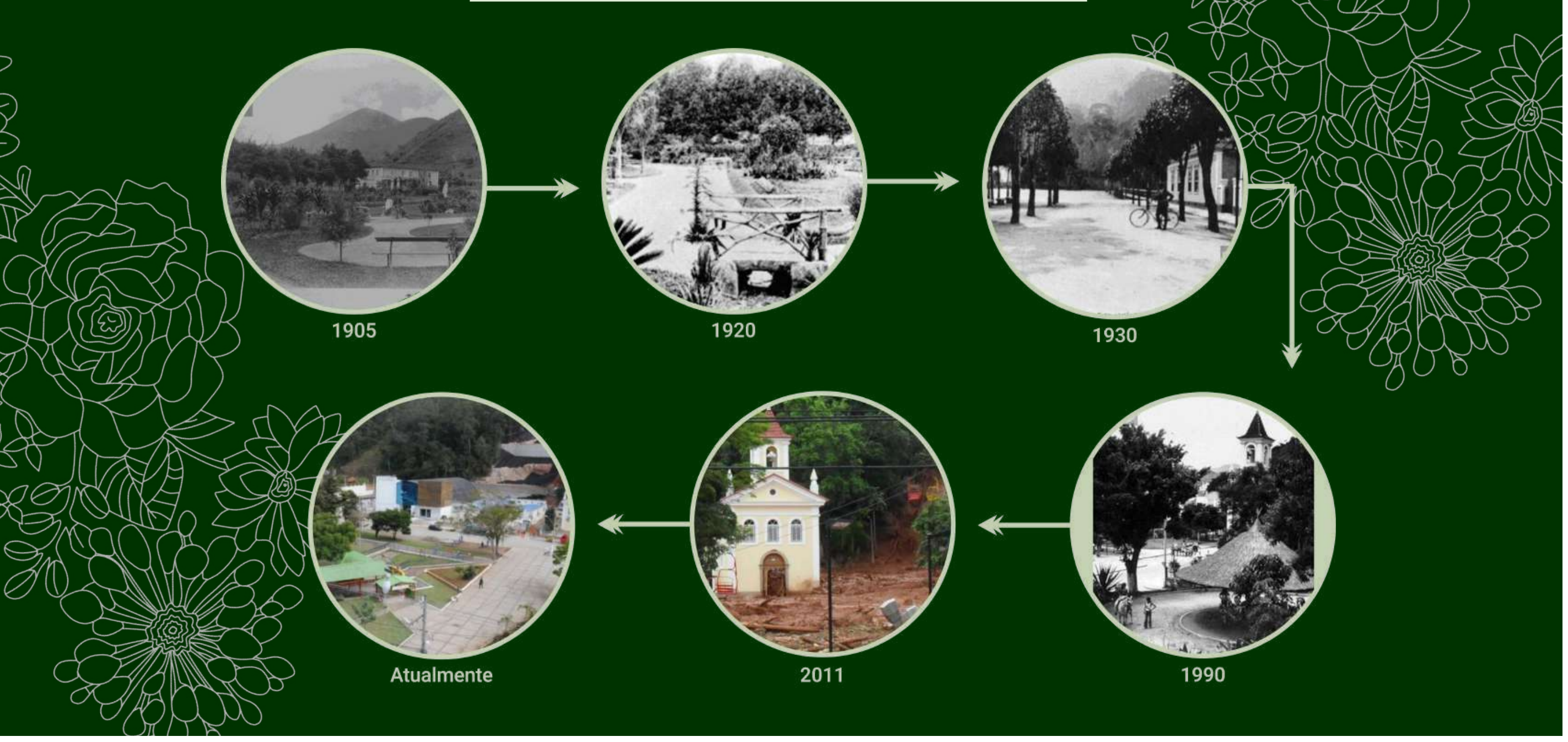




\section{Zoneamento}

Zona Especial de Preservação NÃO RESIDENCIAL

Afastamento Frontal : $5 \mathrm{~m}$

Afastamento Lateral: 1,5m

Afastamento Fundos: $2 \mathrm{~m}$

Taxa de Ocupação: $70 \%$

Taxa de Permeabilidade: ZERO

Gabarito: 4 Pavimentos

Altura Máxima: 14,4m

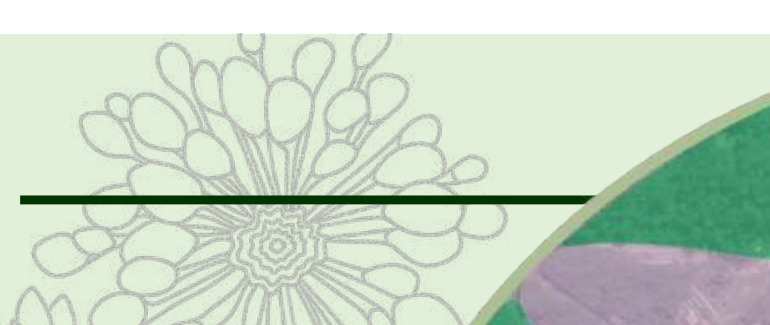




\section{Diagnósticos}




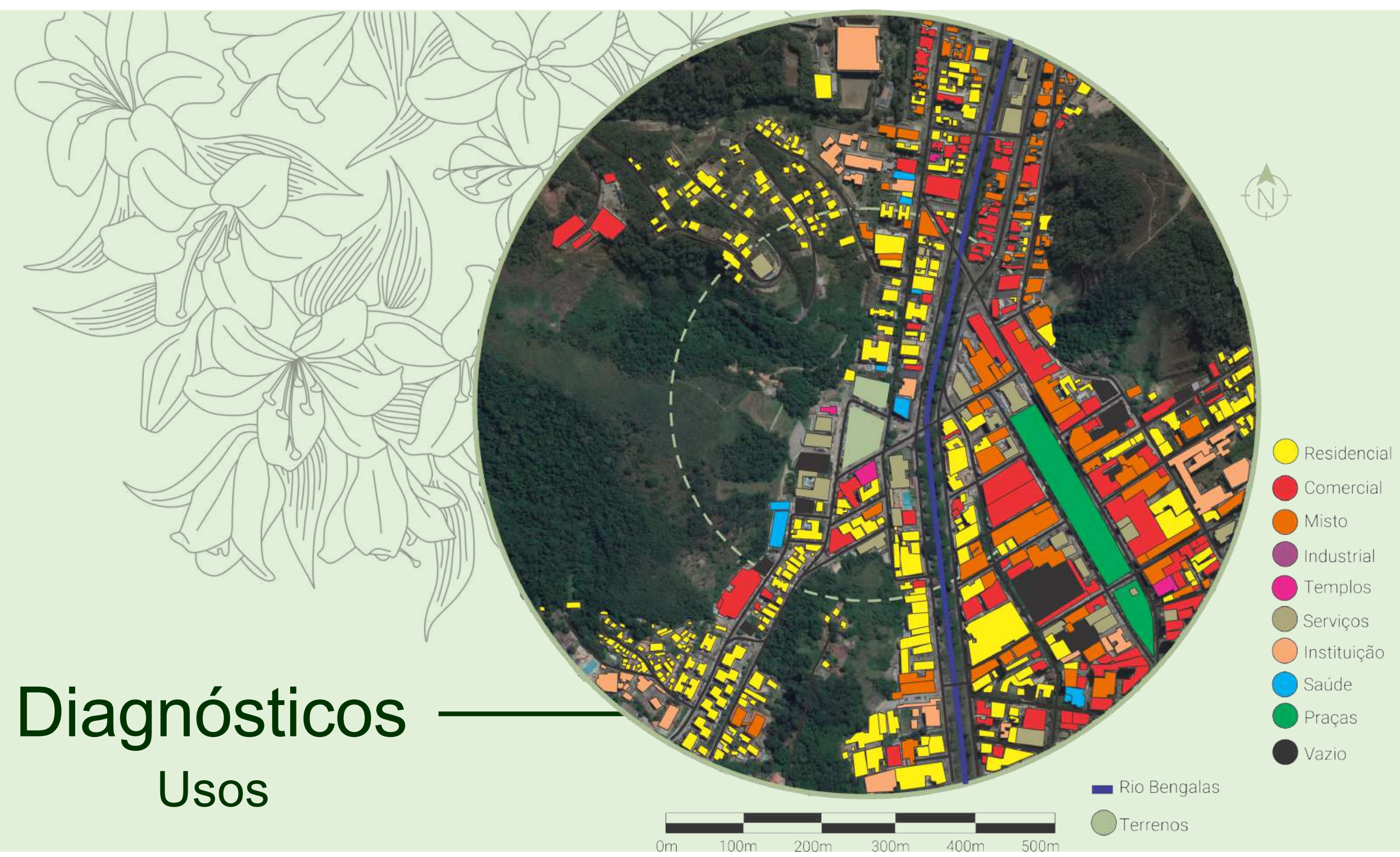




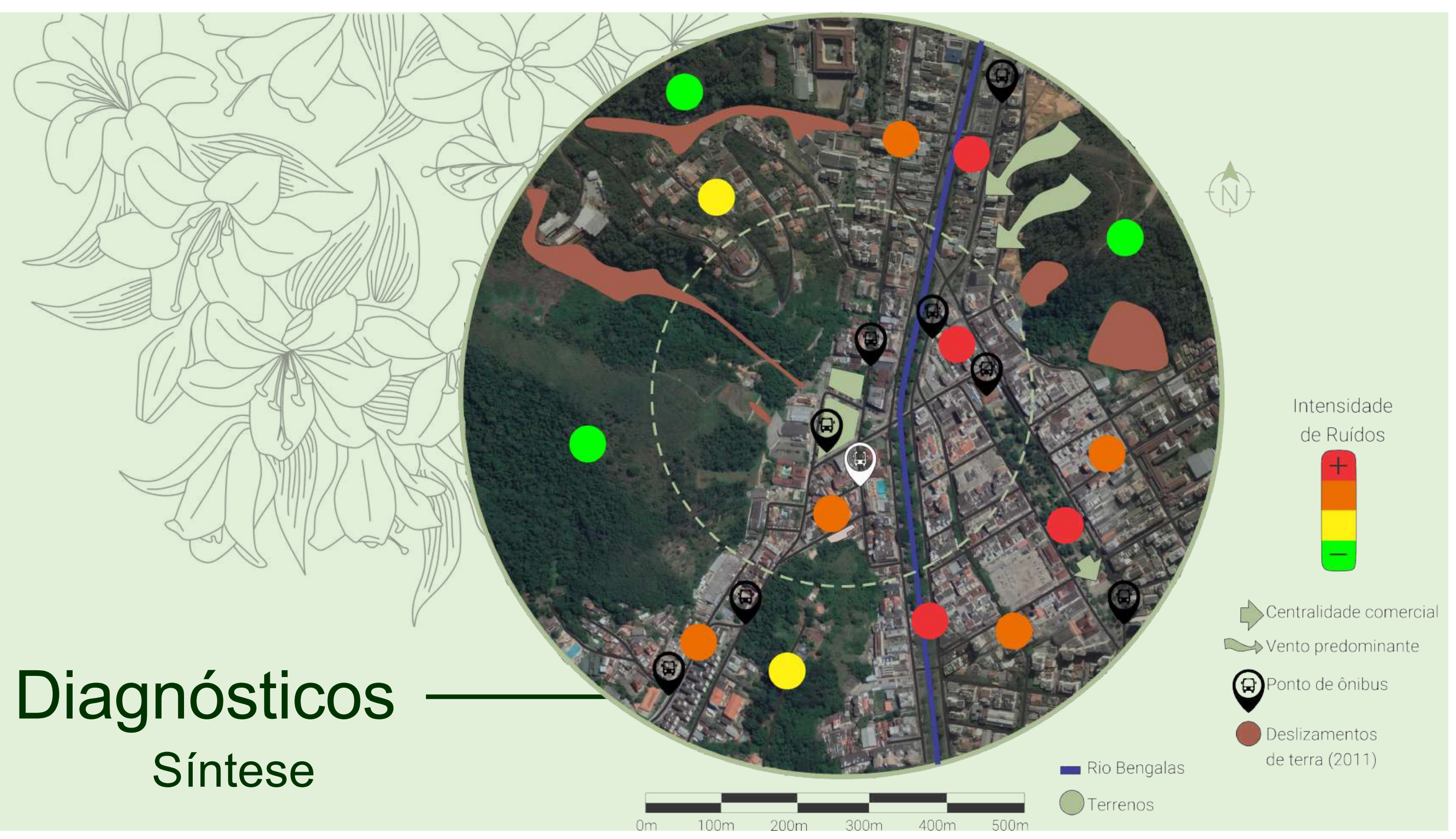




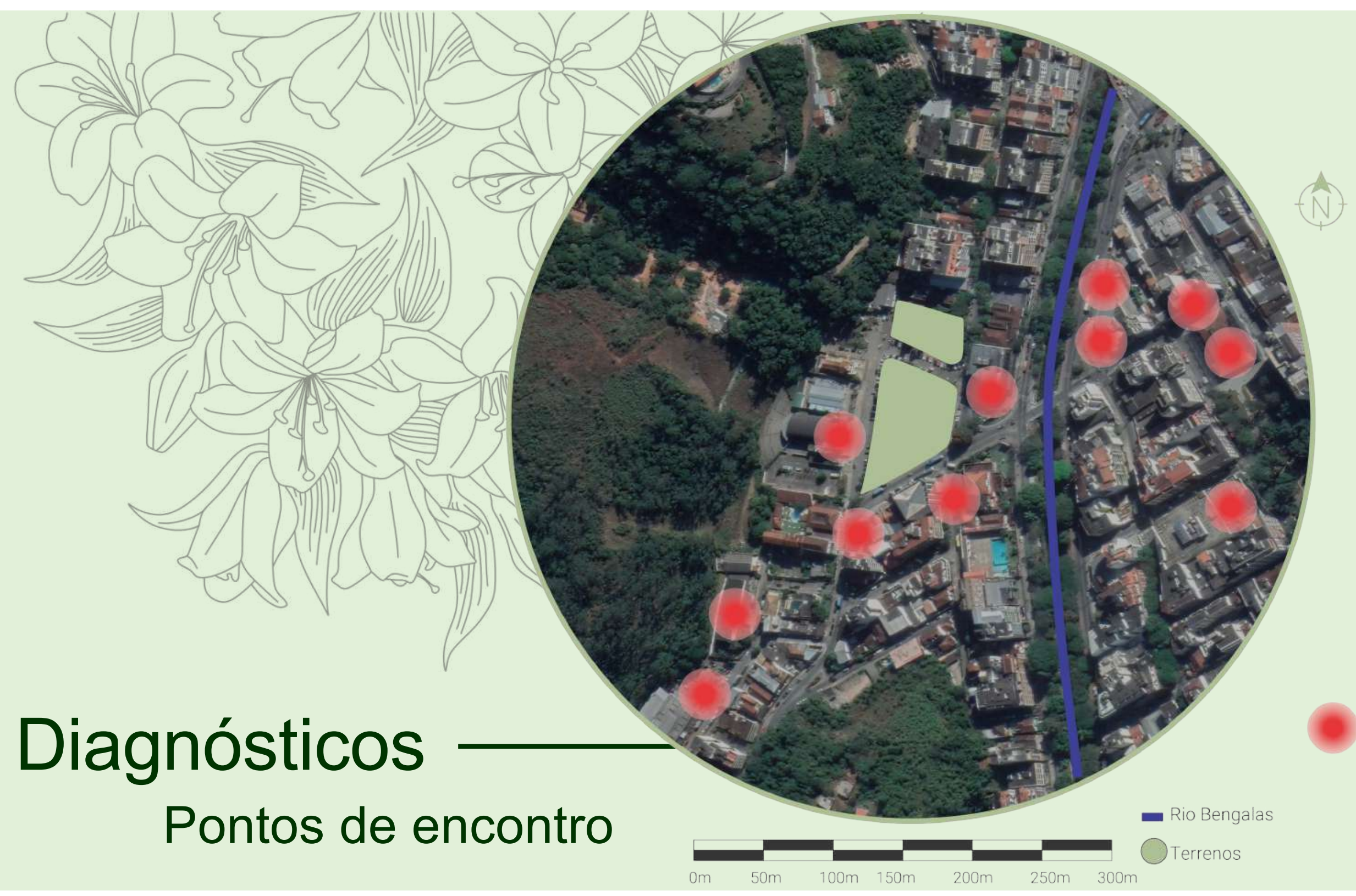




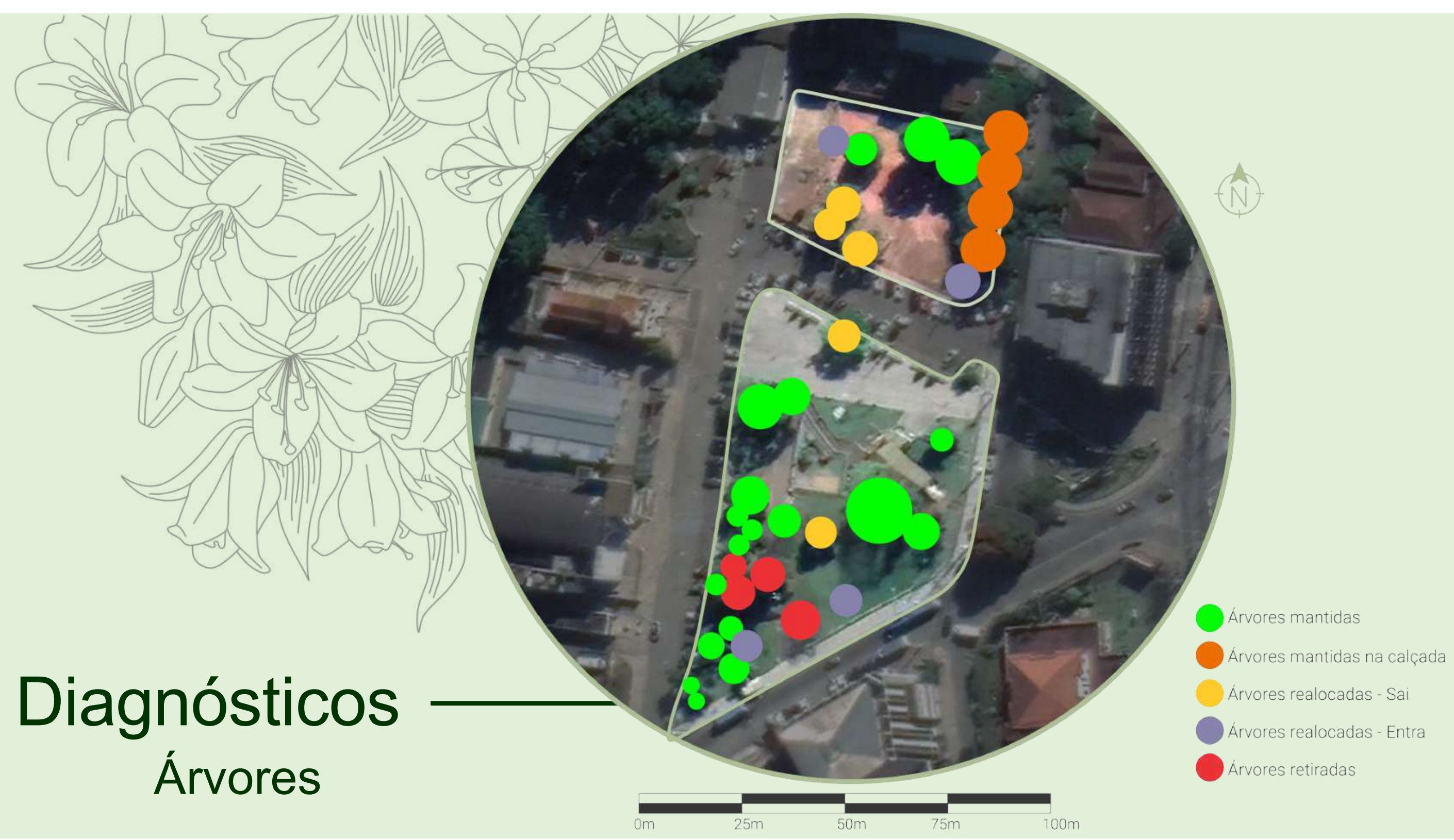




\section{Análise Fofa}

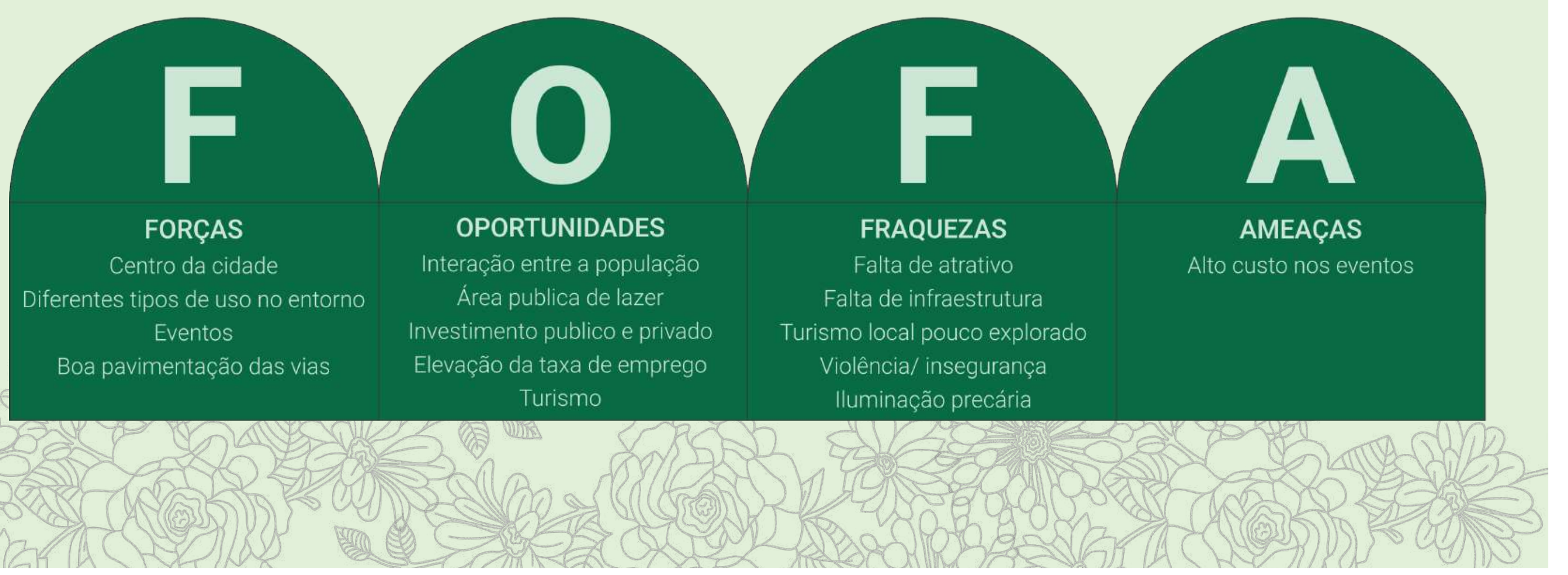




\section{Referências}

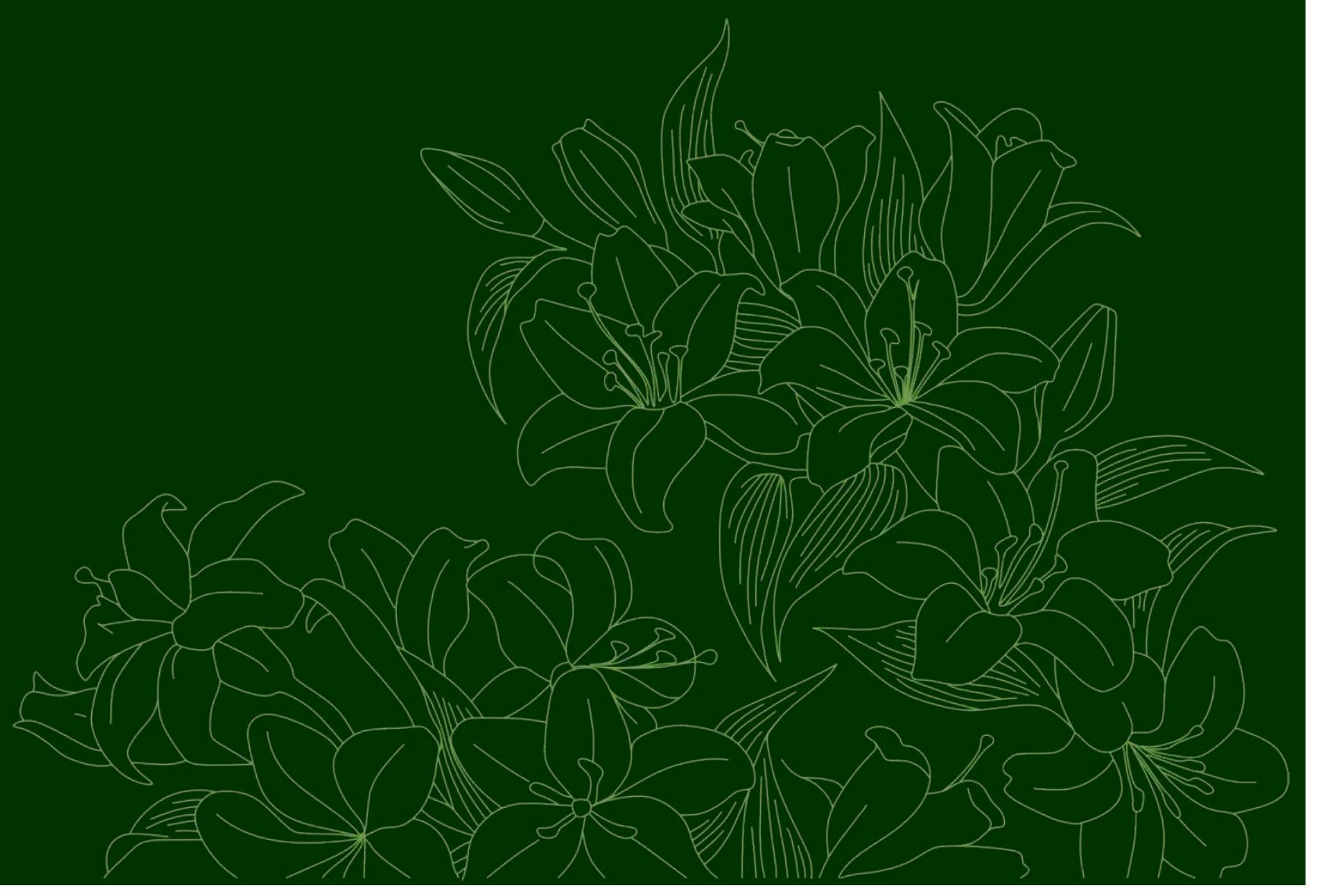




\section{CENTRO CULTURAL}

\section{EL TRANQUE}

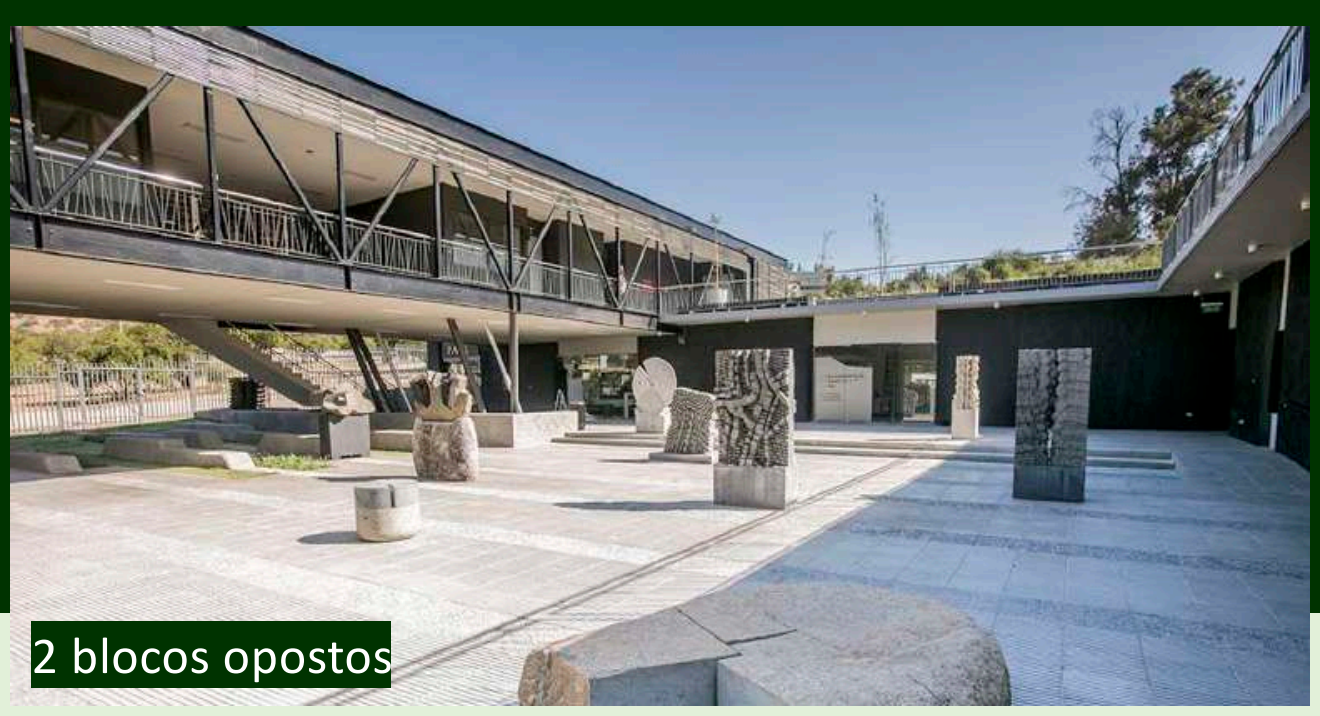

CHILE - 2015 - BiS Arquitectos - 1400m²
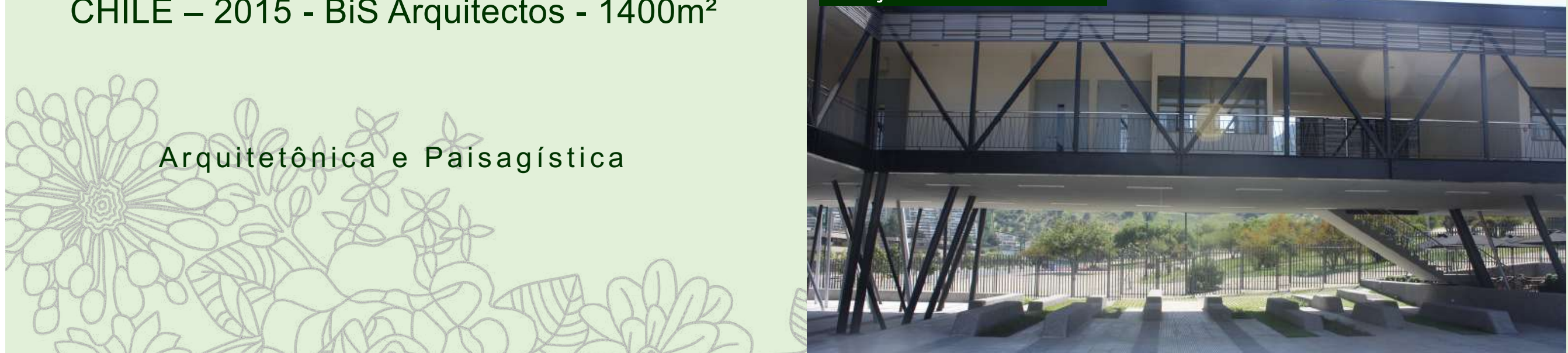


\section{PRAÇA TRIUMFALNAYA}

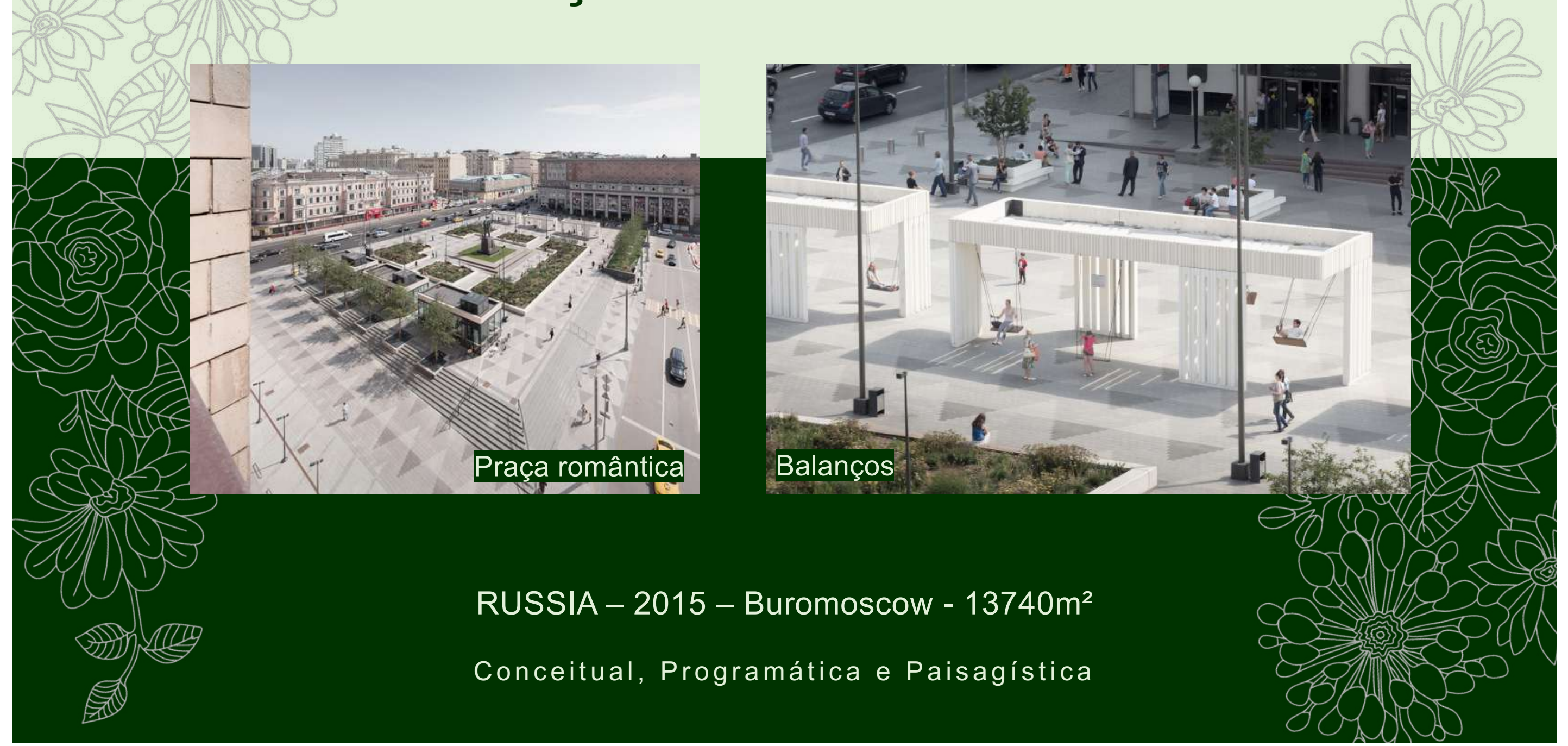




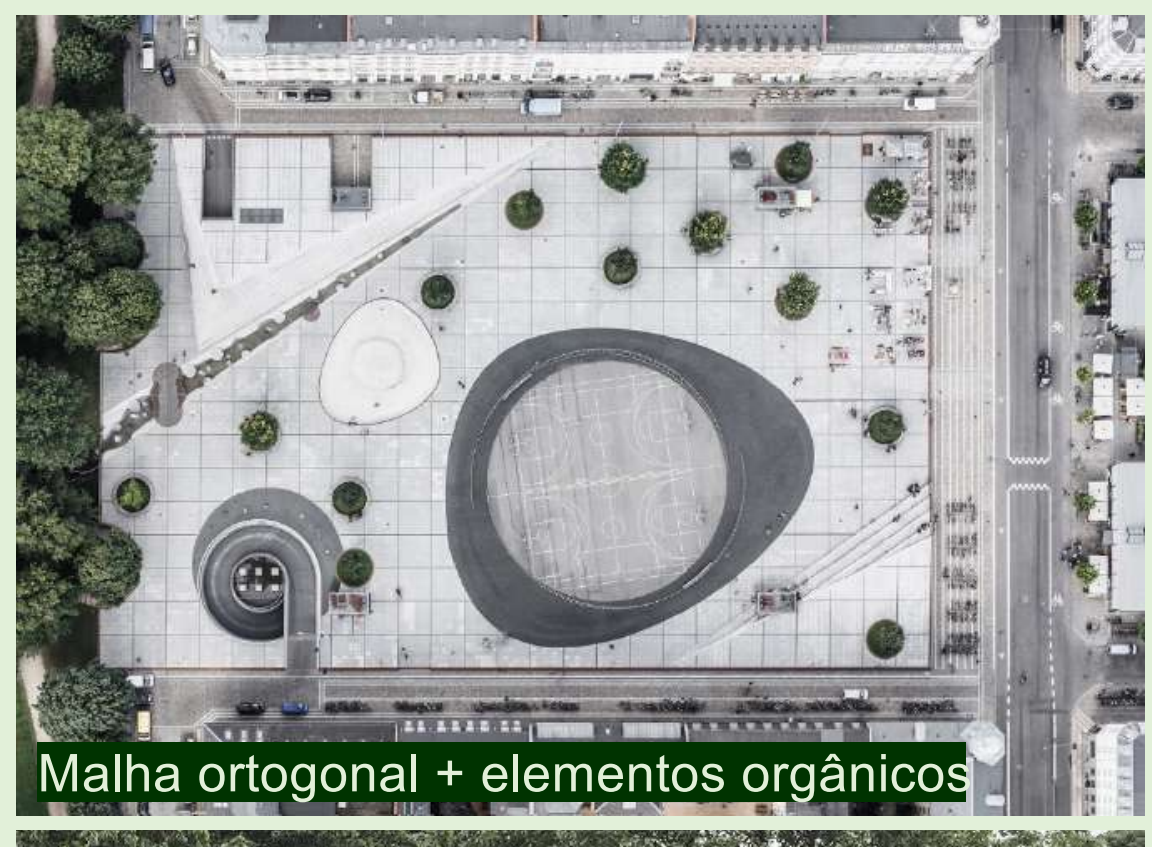

\title{
PRAÇA ISRAEL PLADS
}

\author{
DINAMARCA - 2014 - COBE - 12500m²
}

Conceitual, Arquitetônica e Programática

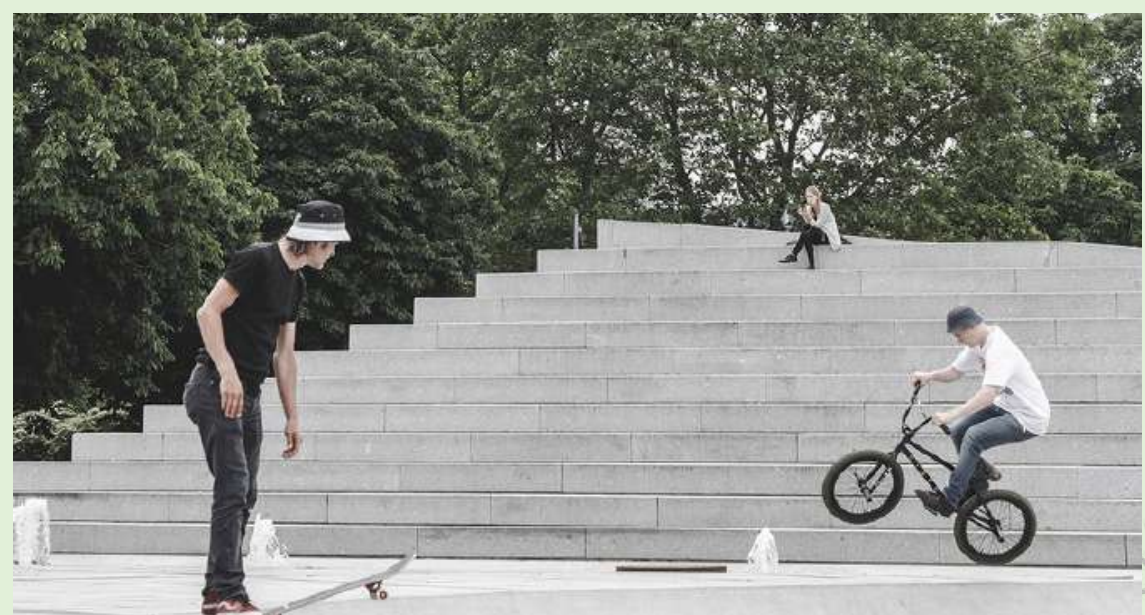

Esportes de rua + arquibancade 


\section{Proposta}

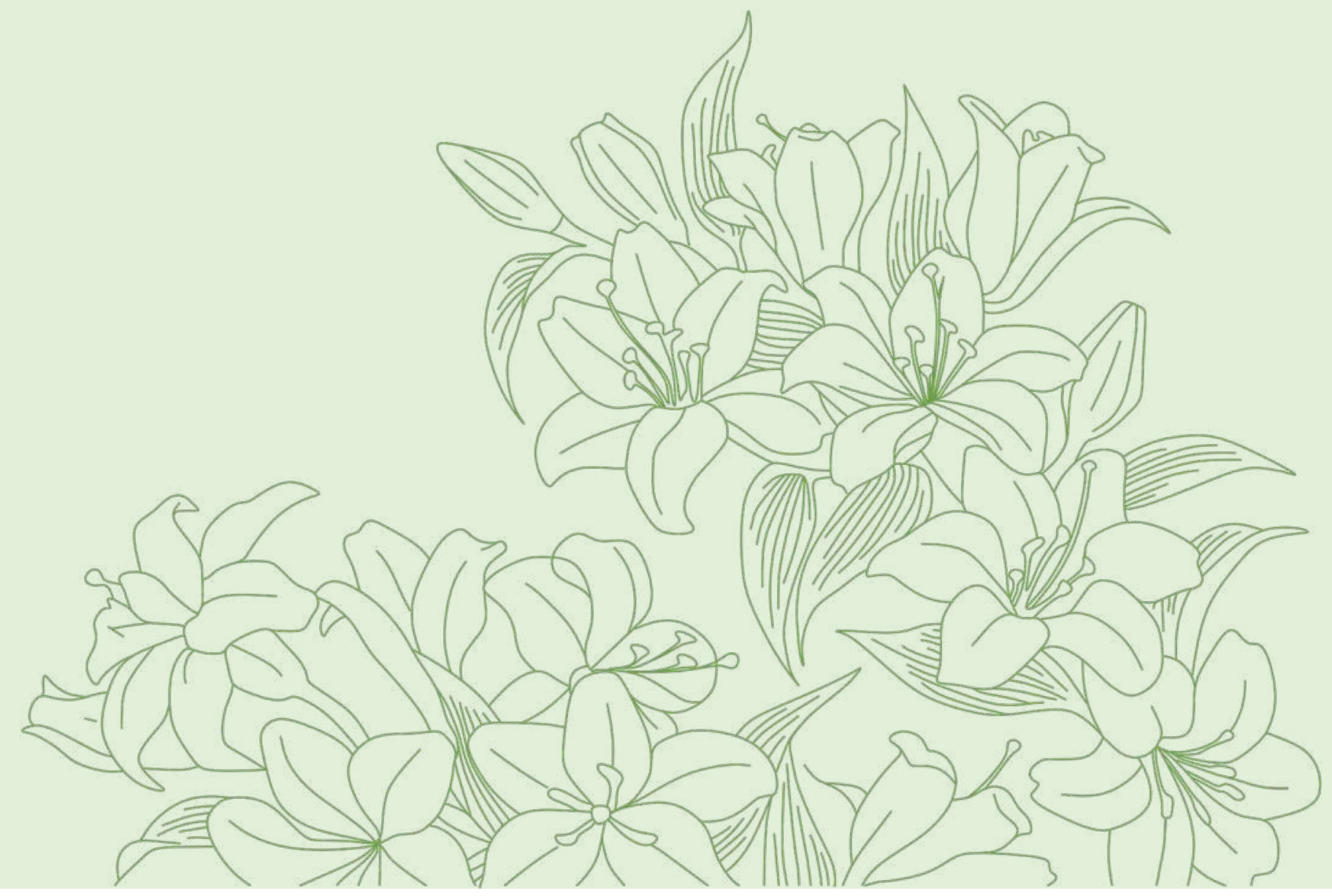




\section{Conceito / Partido}

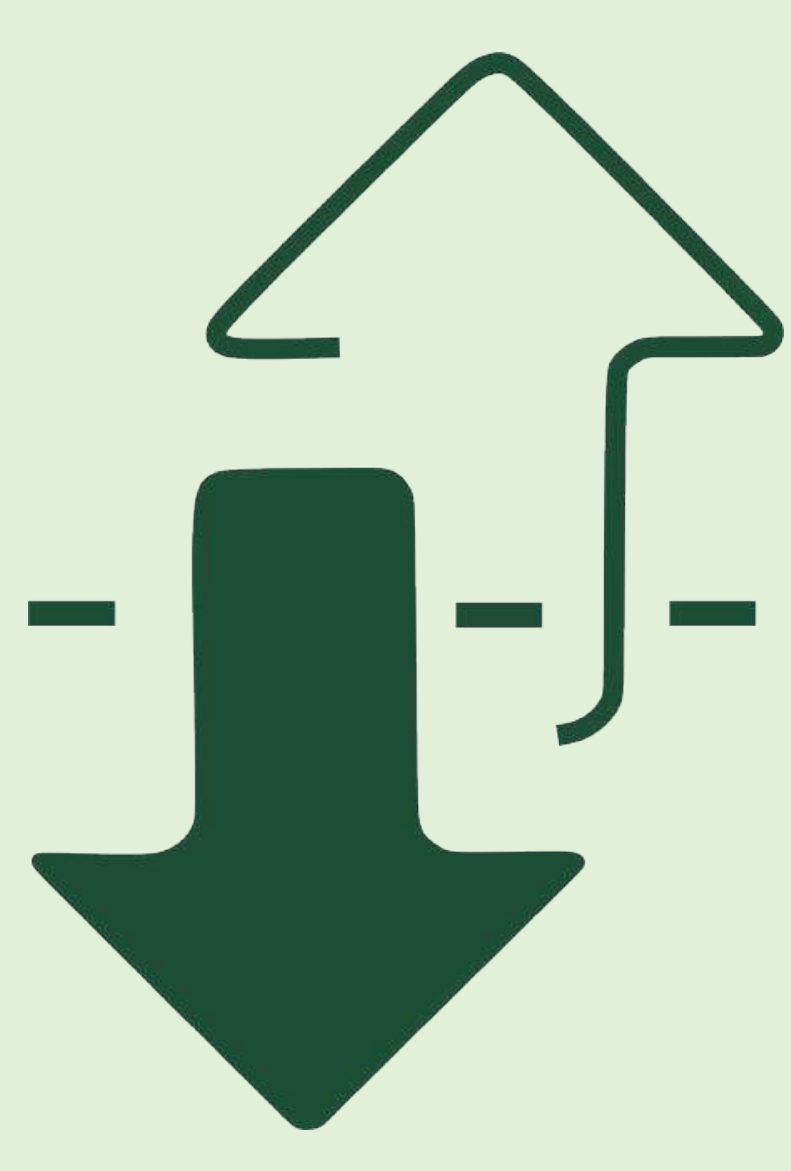

\section{Integração}

- União entre a Praça e o terreno

- Diversidade de atividades multiplas para diferentes conjuntos de pessoas

- Esportes de rua

- Exercícios físicos

- Parque infantil

- Jardim de contemplação

- Centro Cultural

- Vidro: promovendo a continuidade do espaço

- Materiais naturais: aproximando o indivíduo da praça 

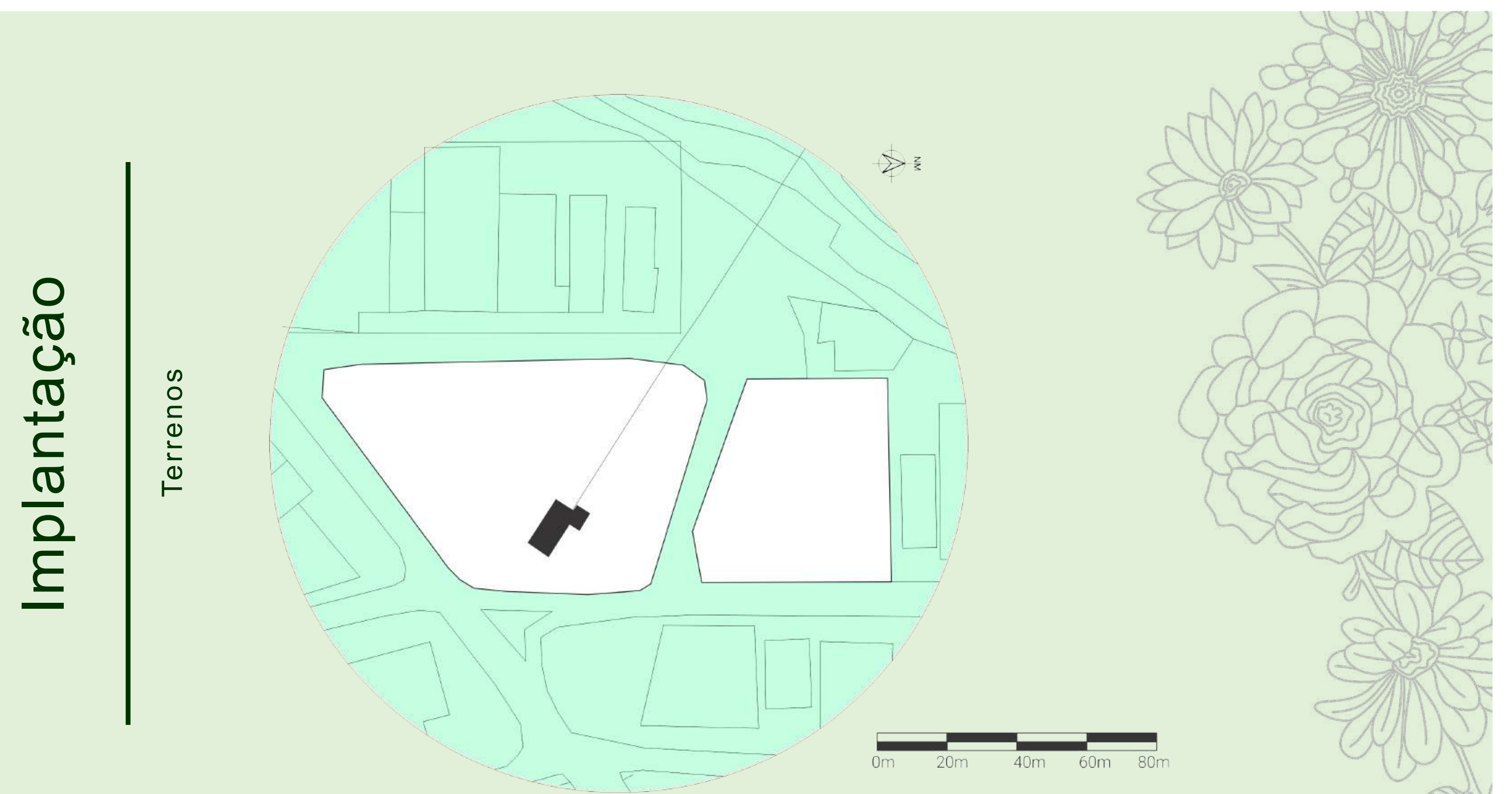

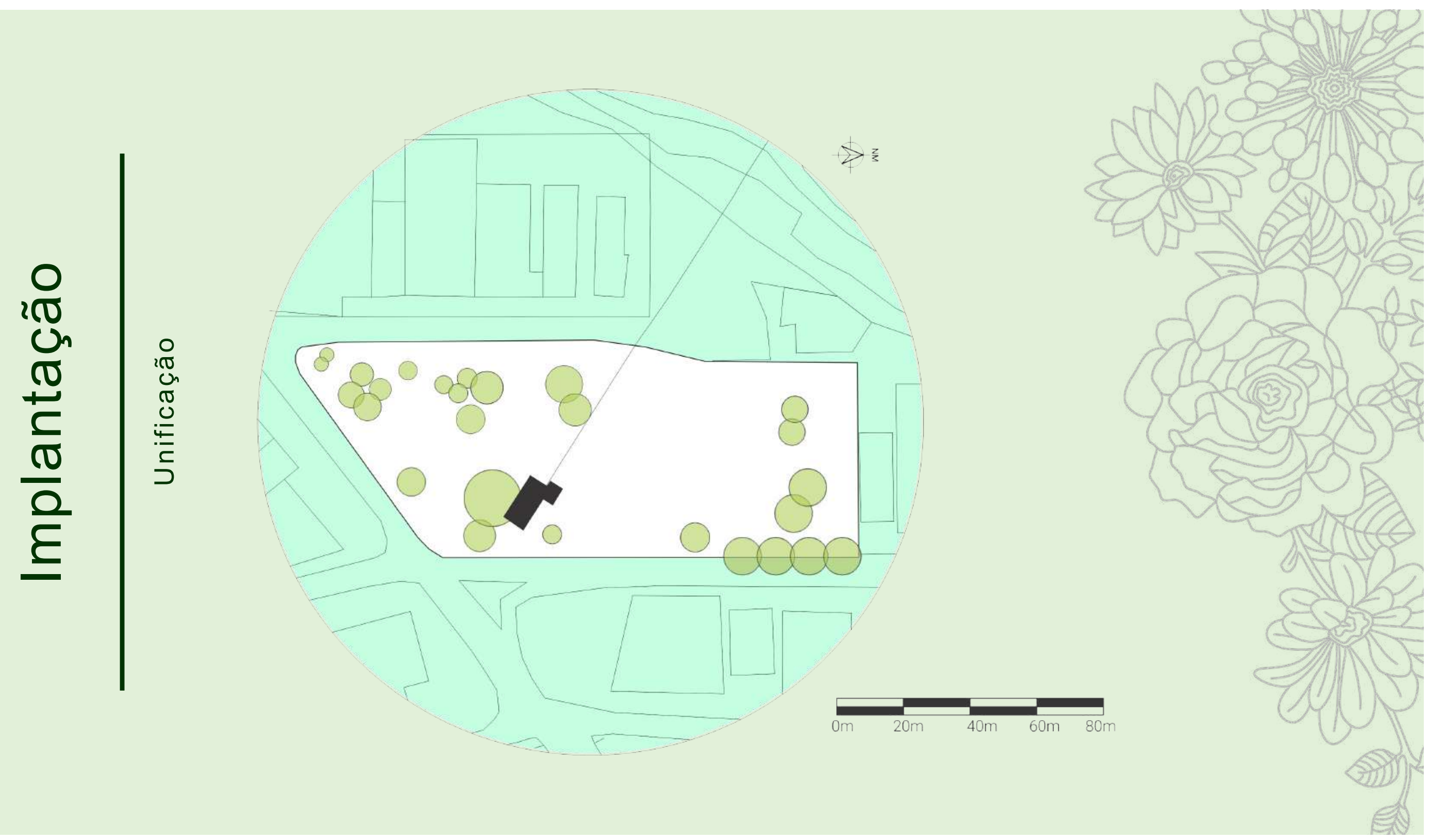

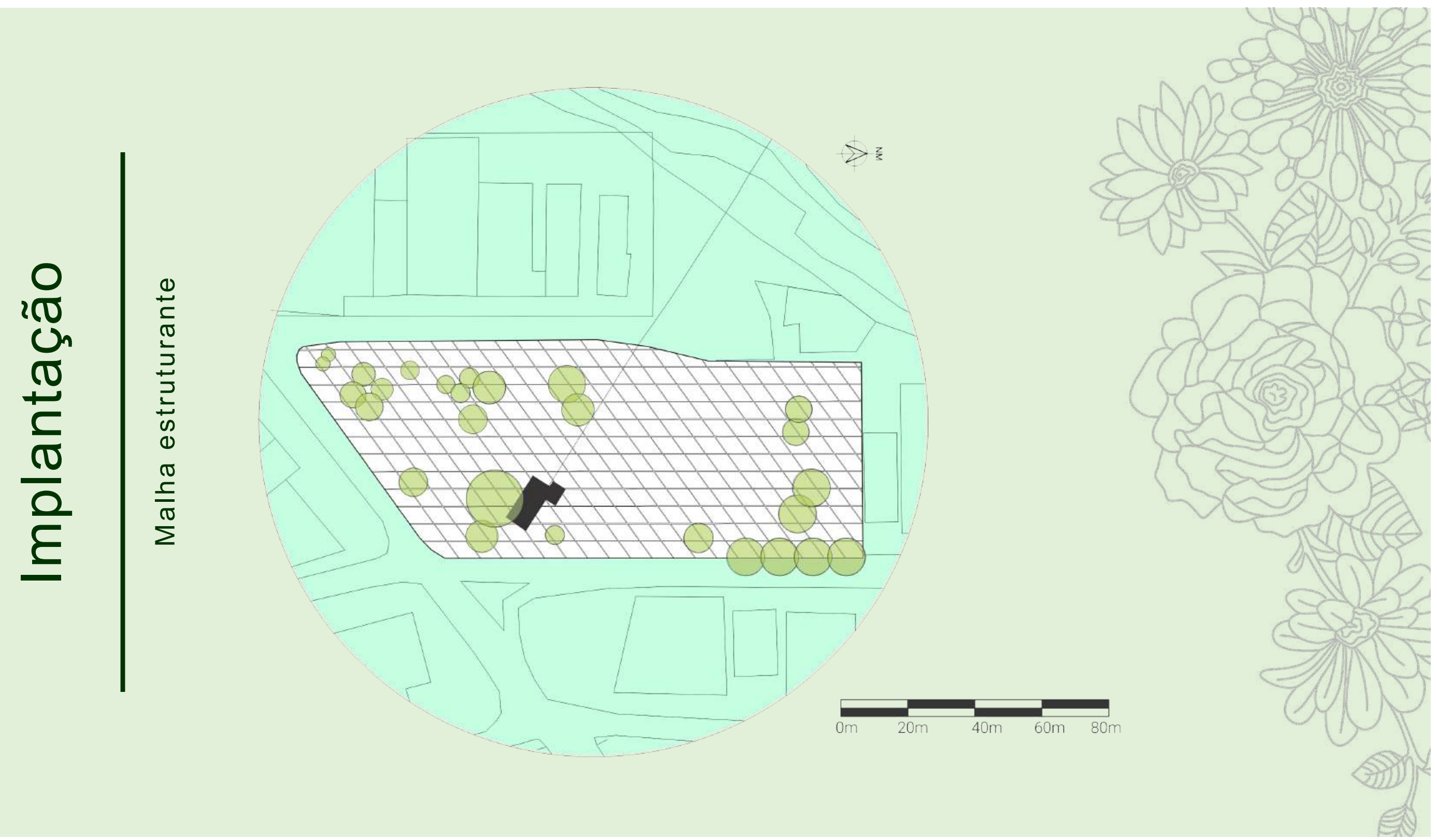

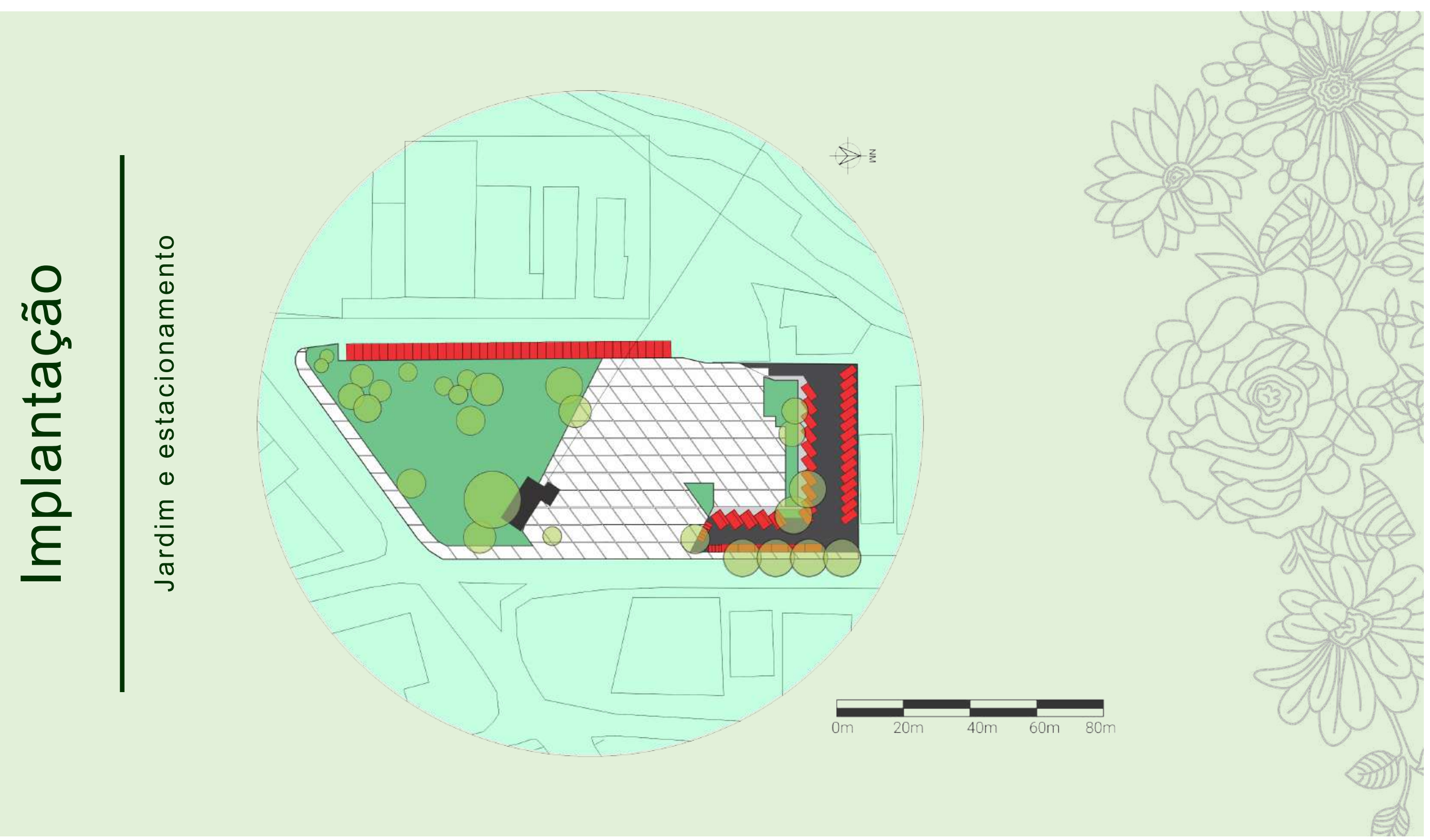


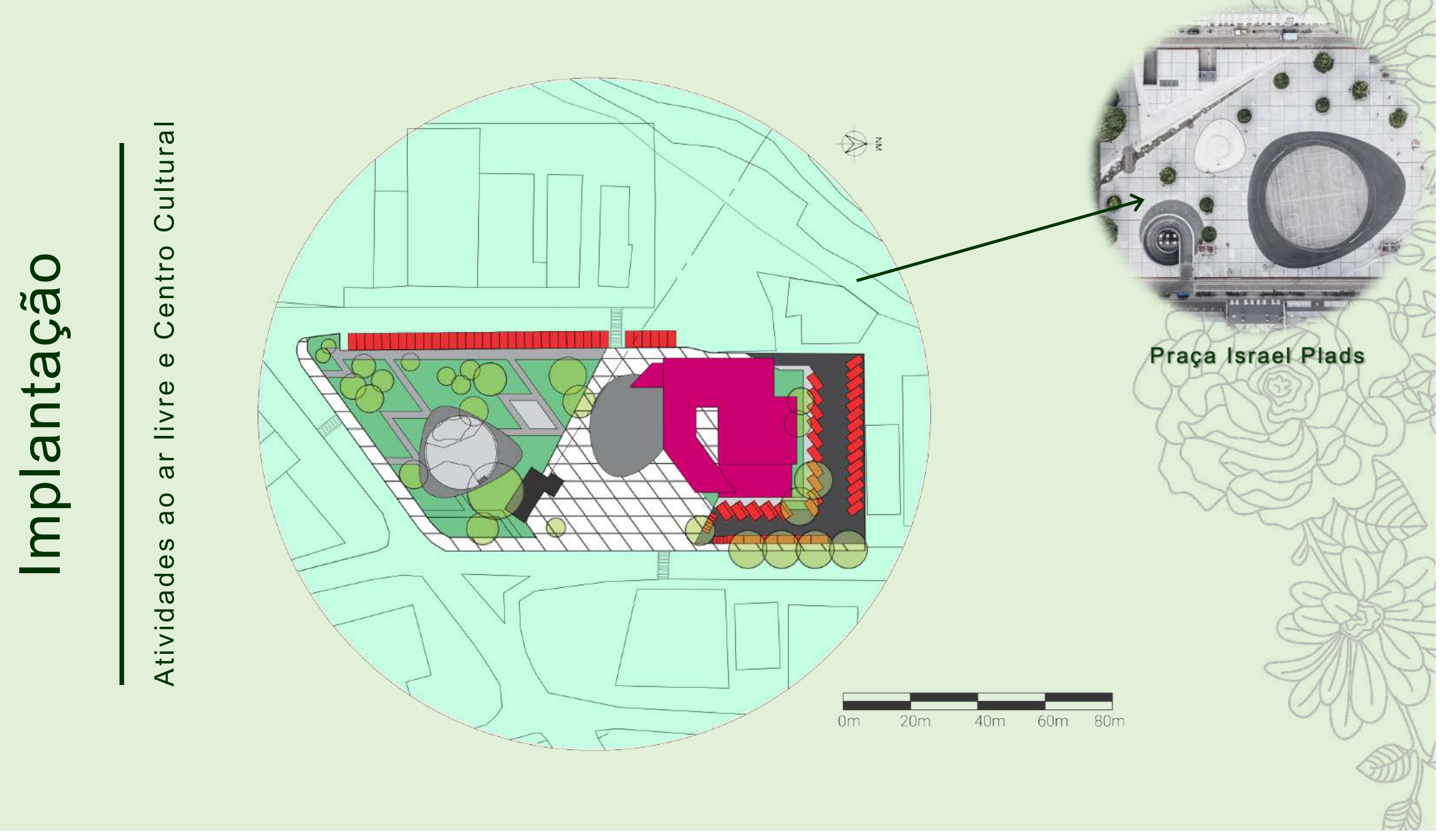




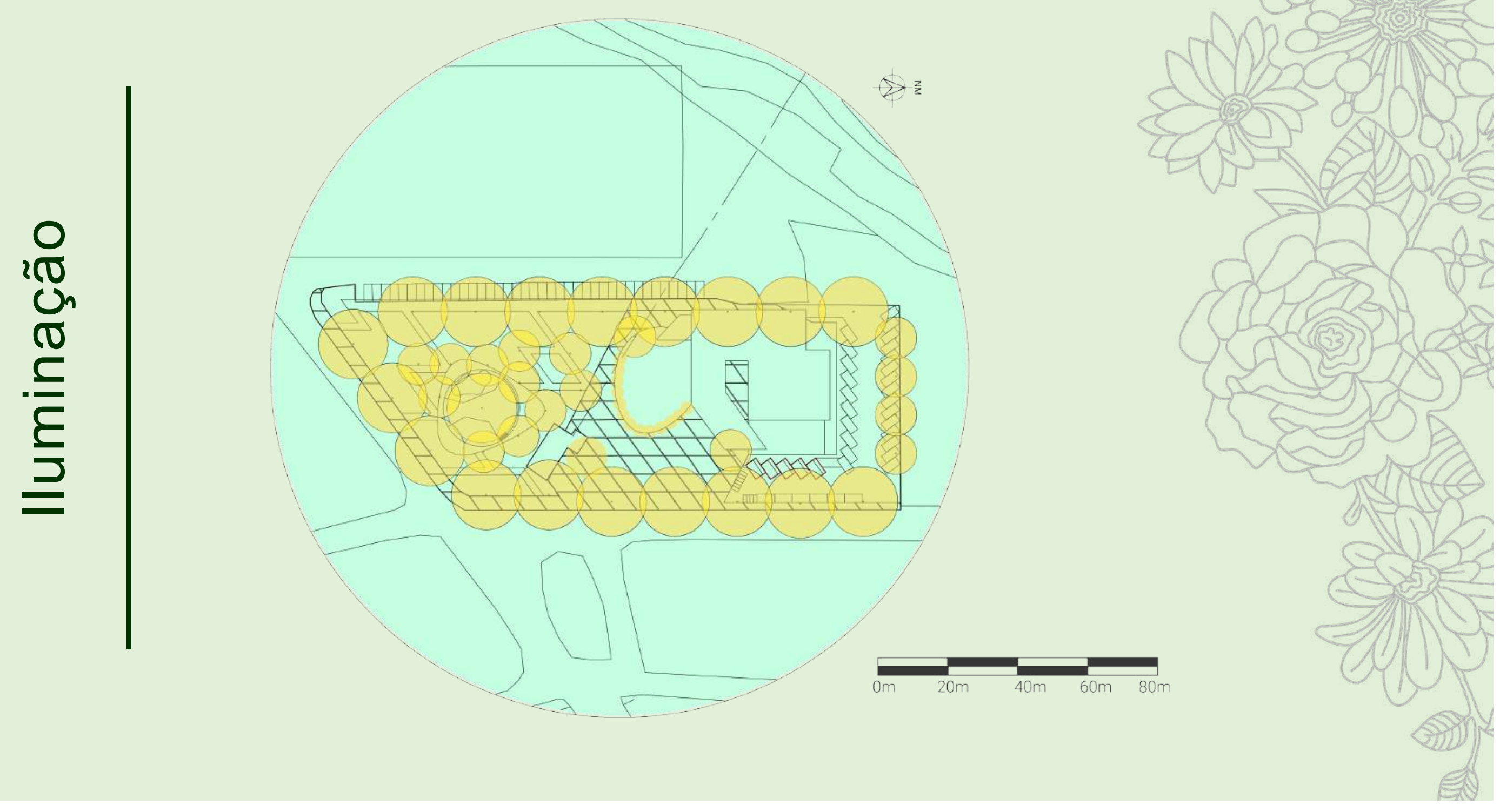



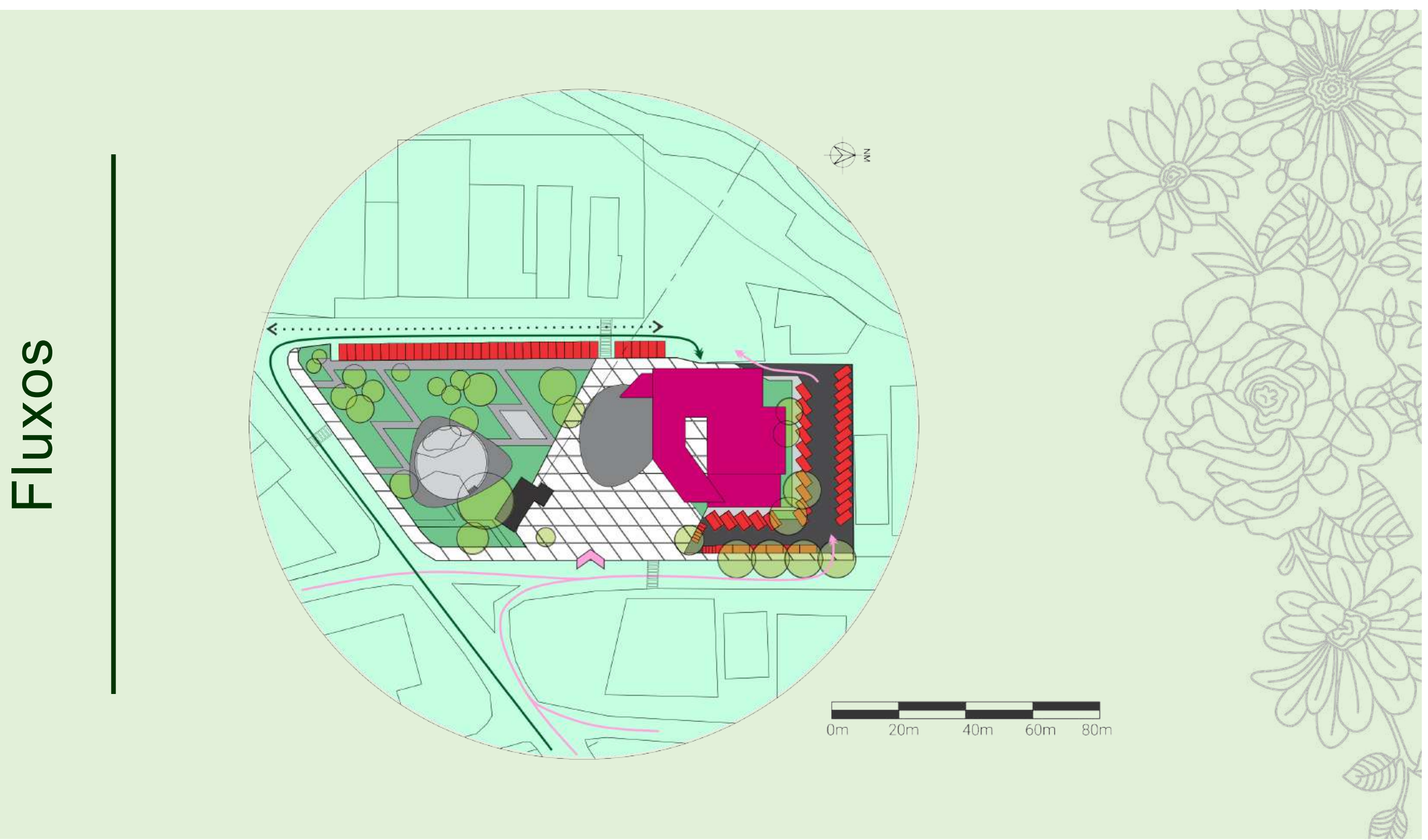


\section{Sistema Estrutural}

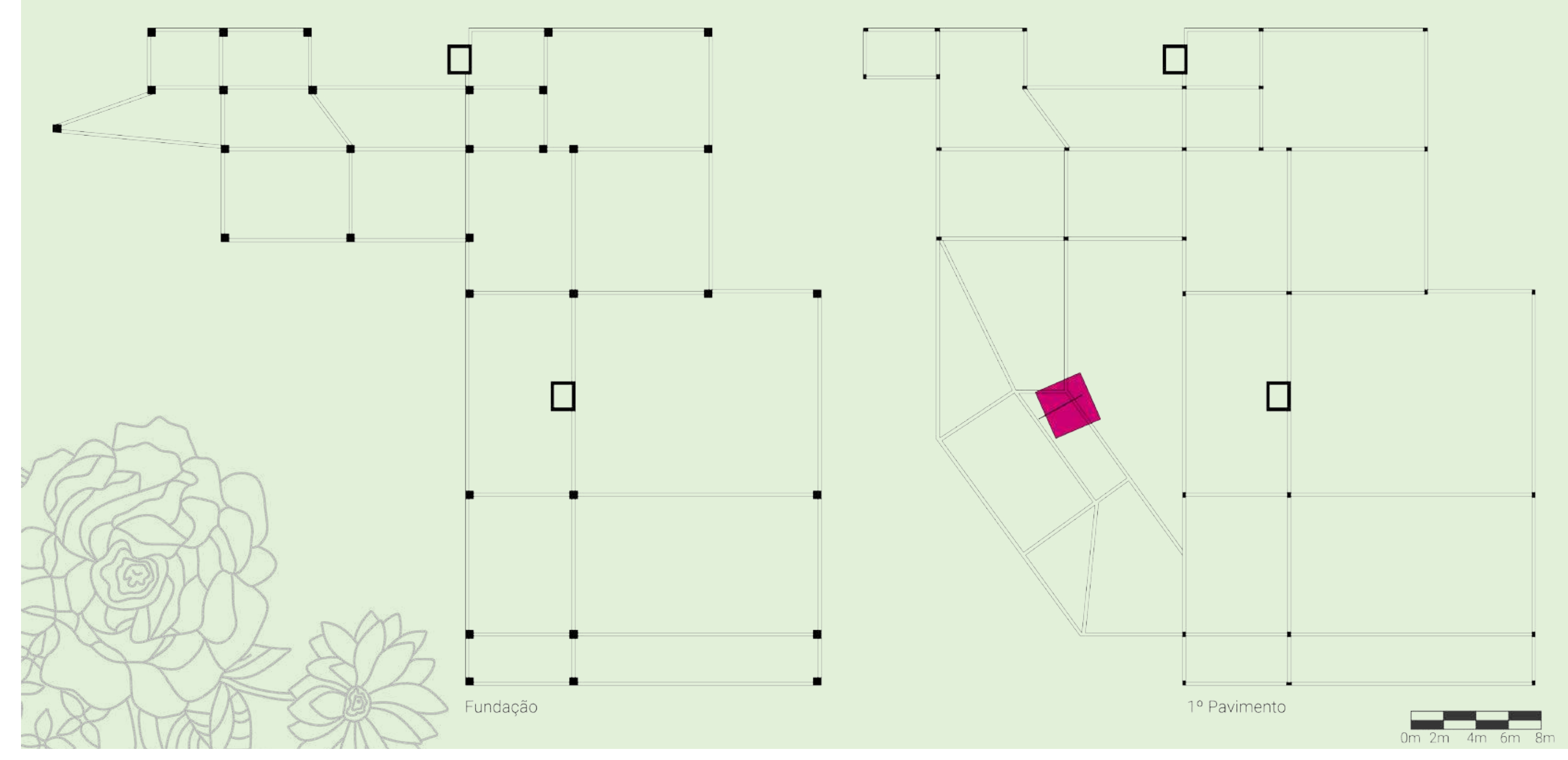




\section{Sistema Estrutural}

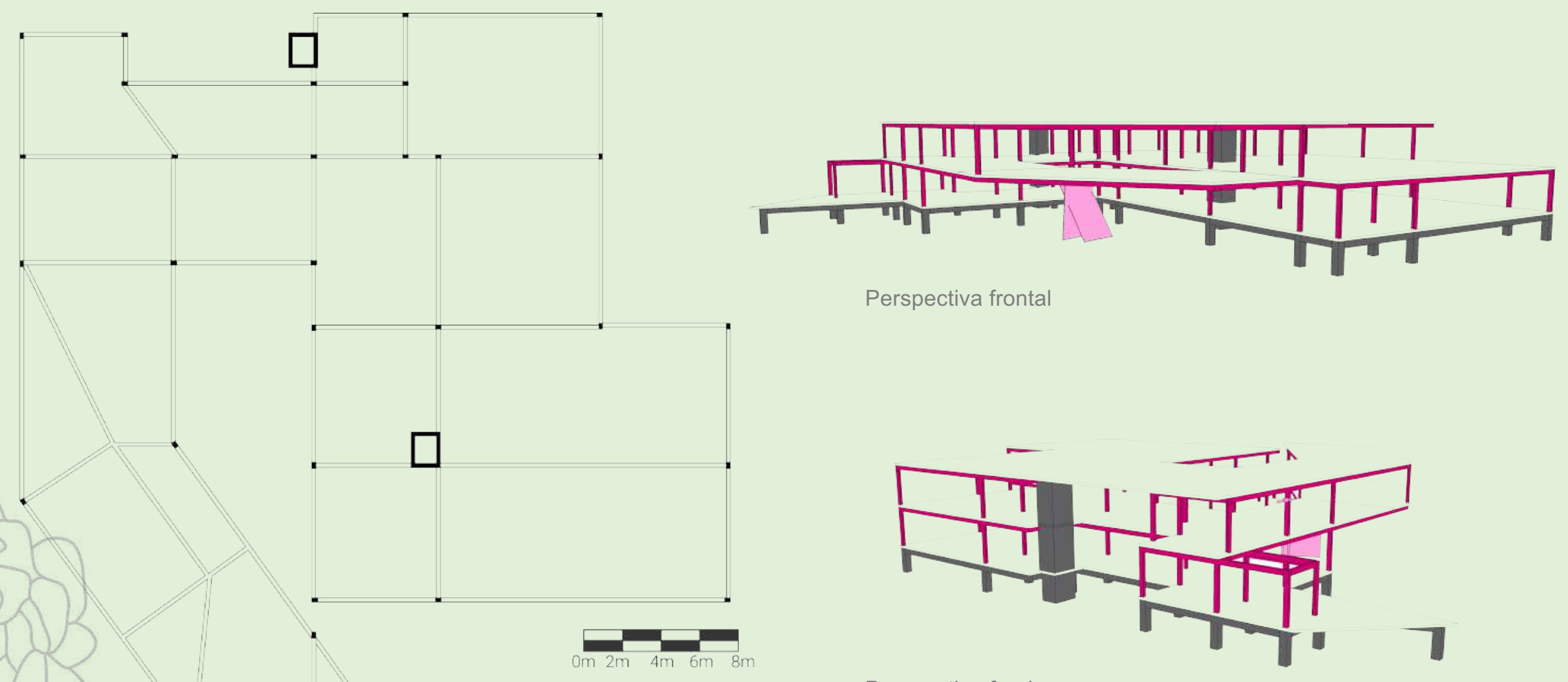

Perspectiva fundos 


\section{Vistas Gerais}
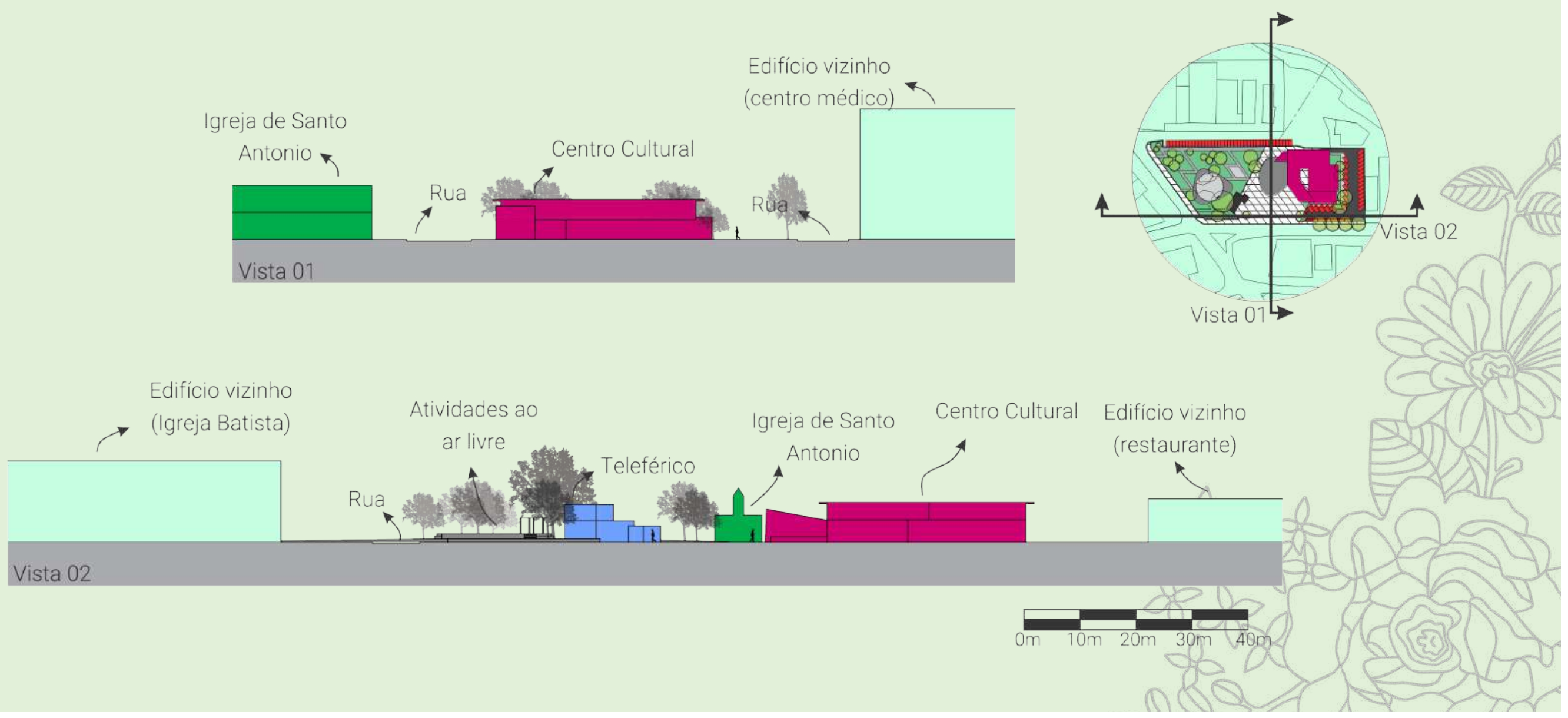


\section{Paisagismo}
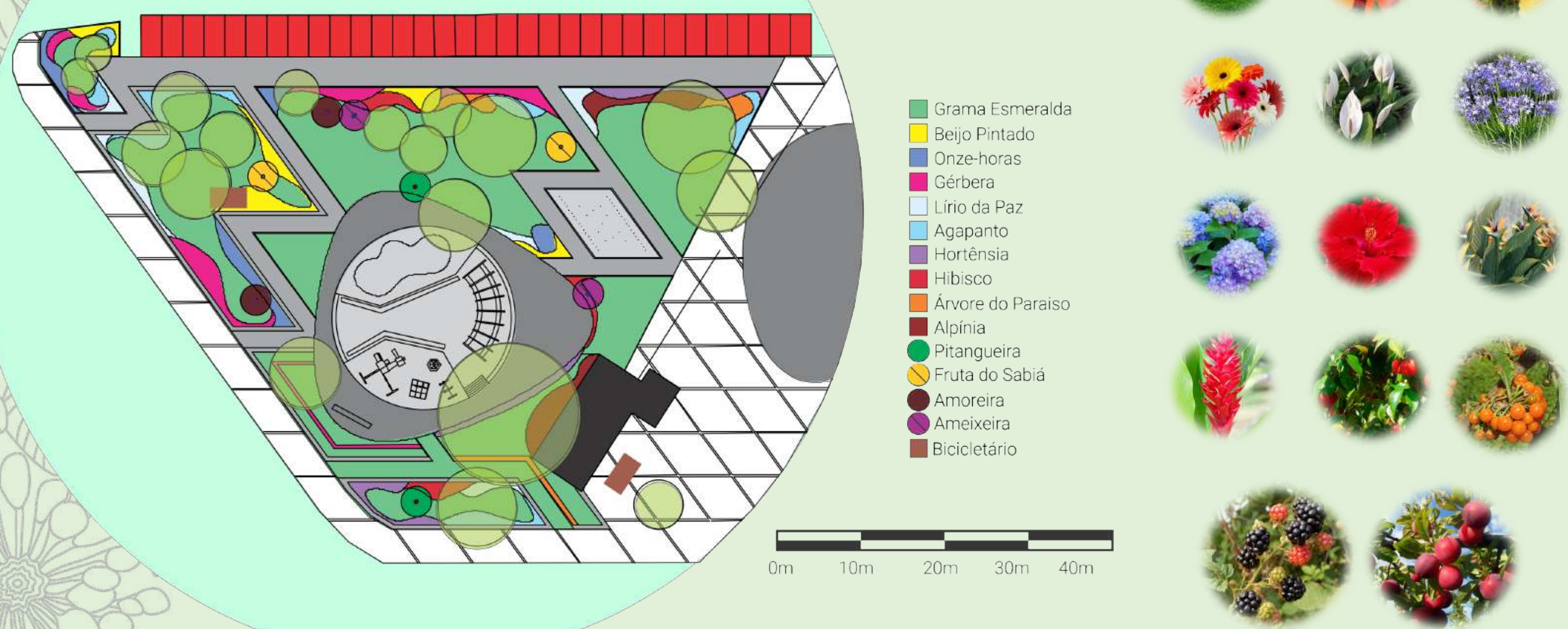


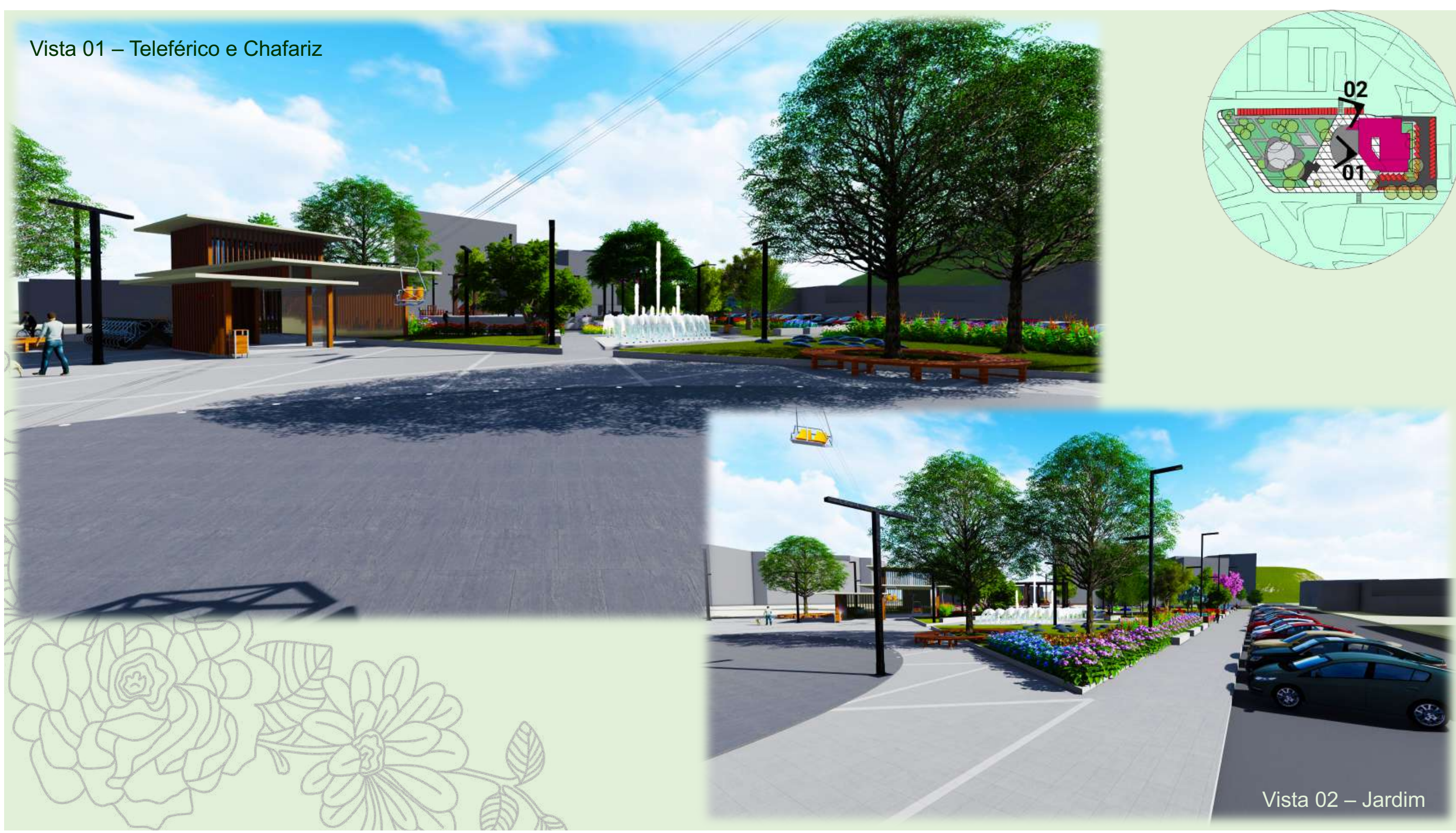



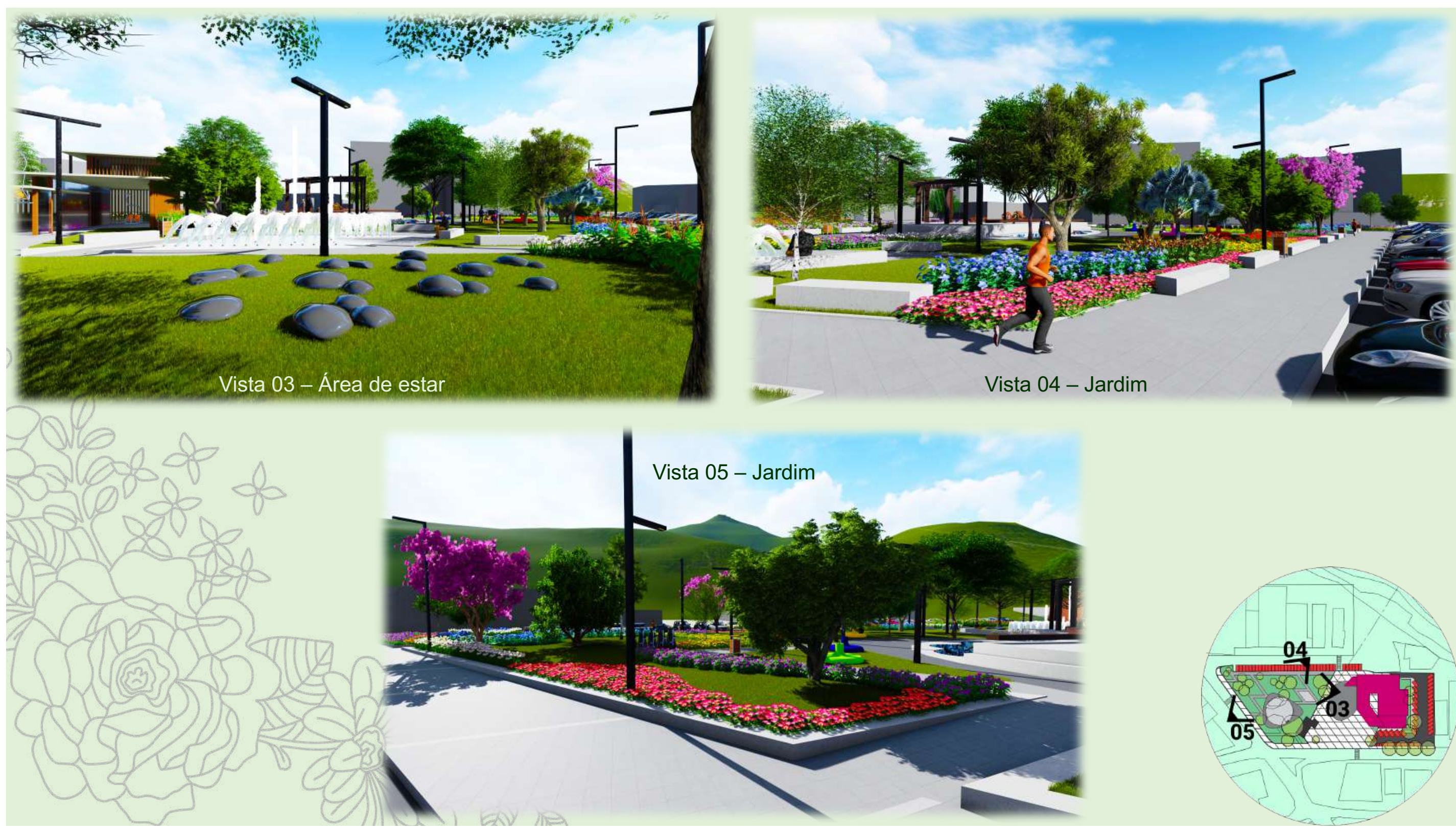


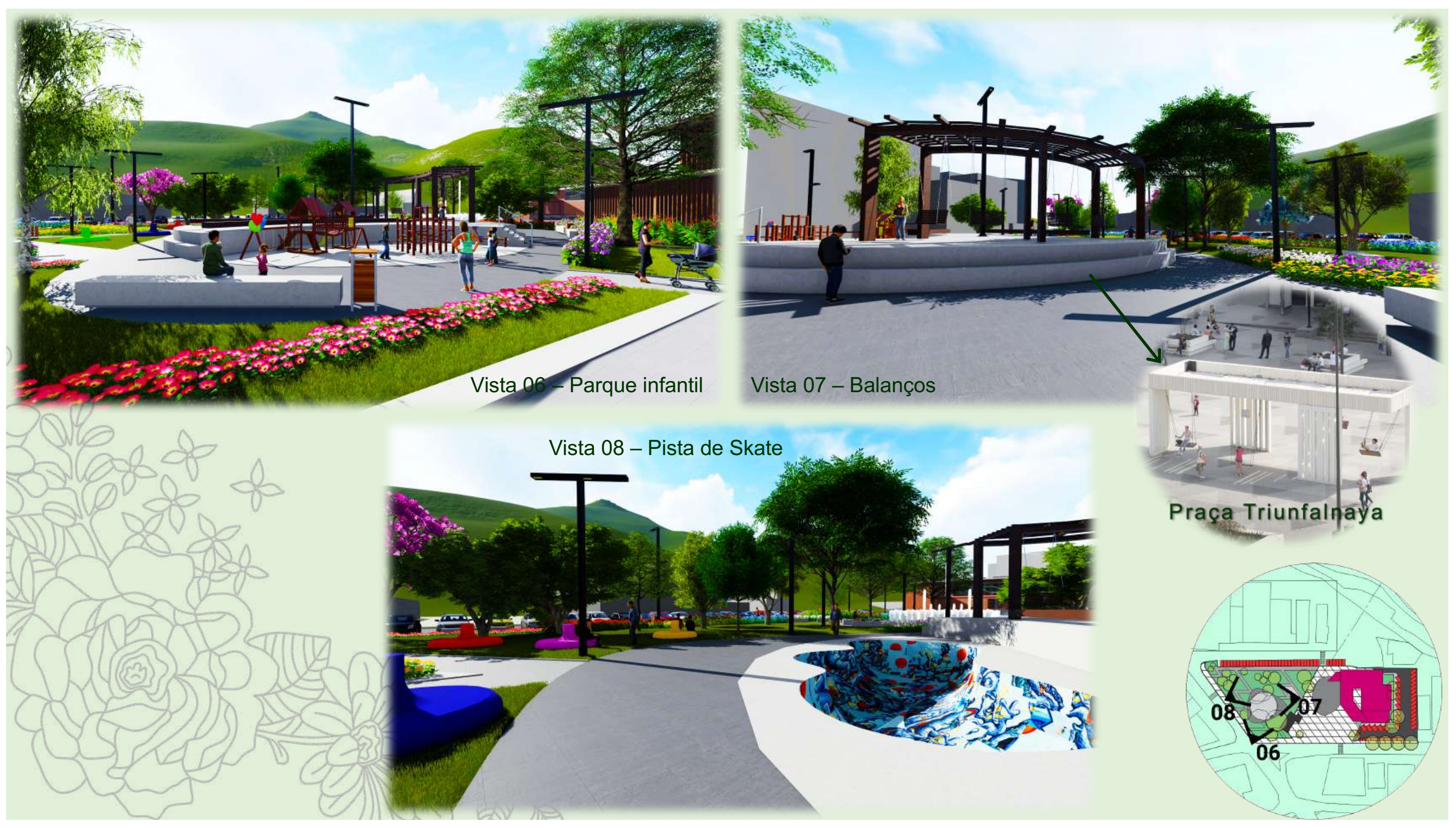




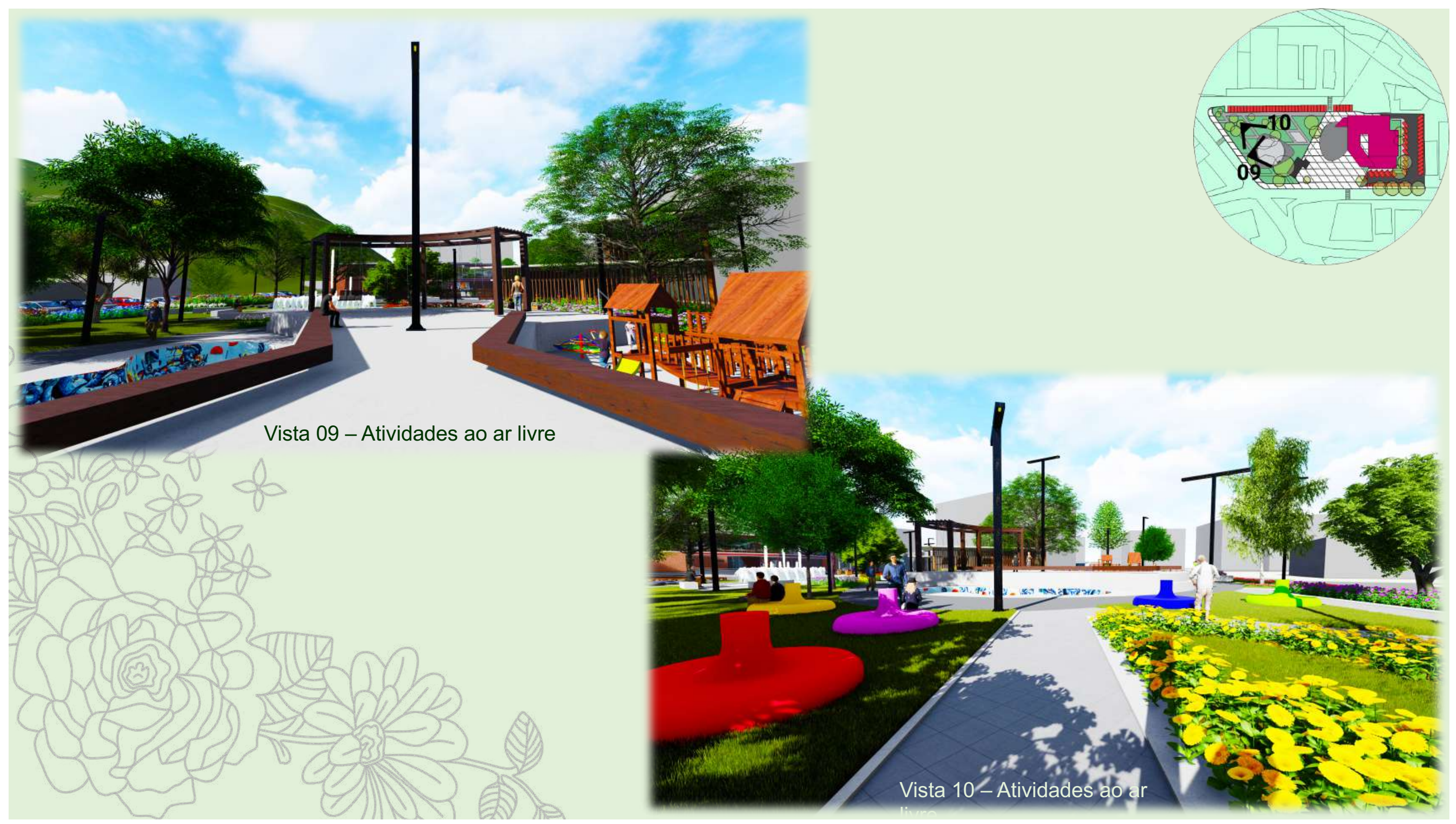




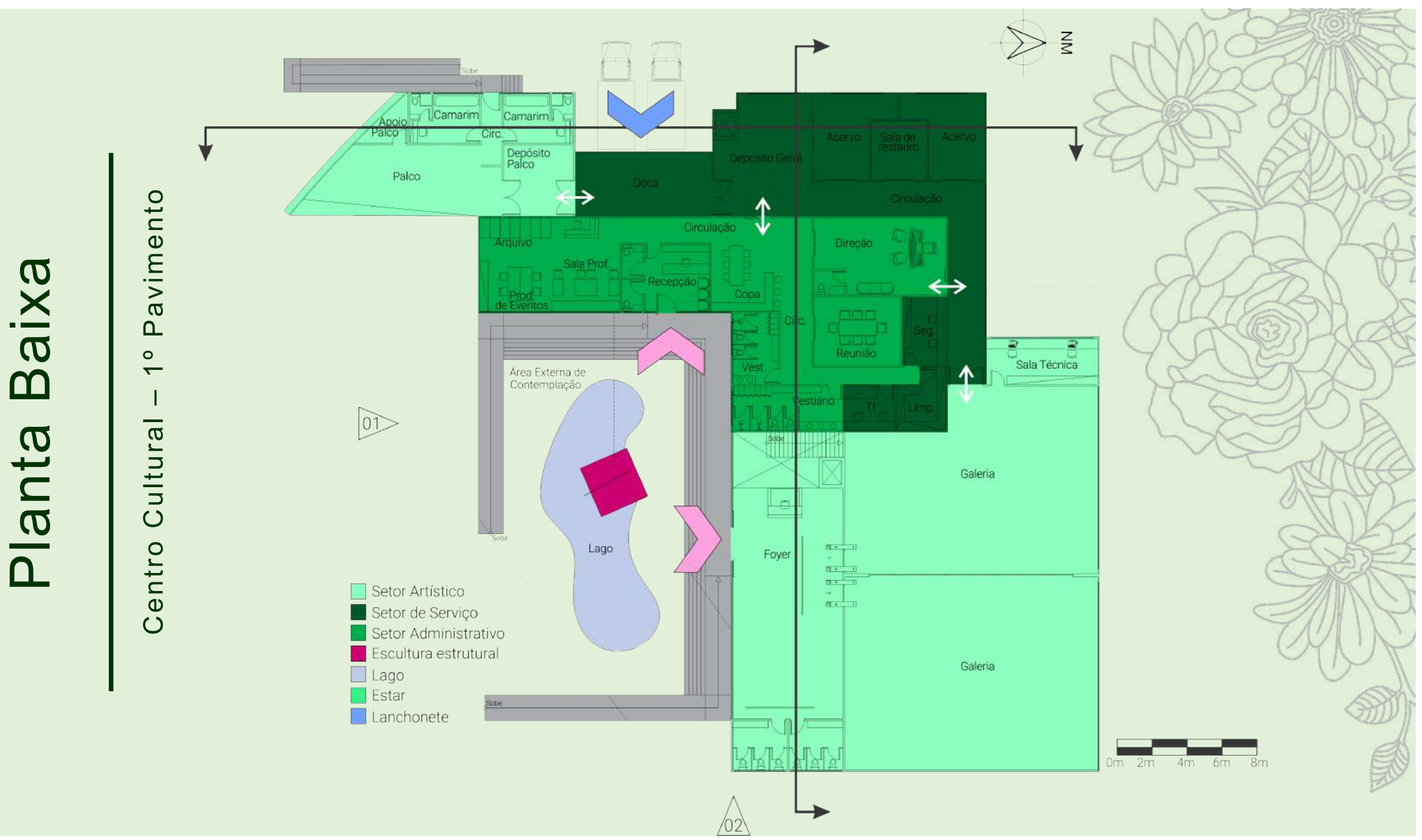




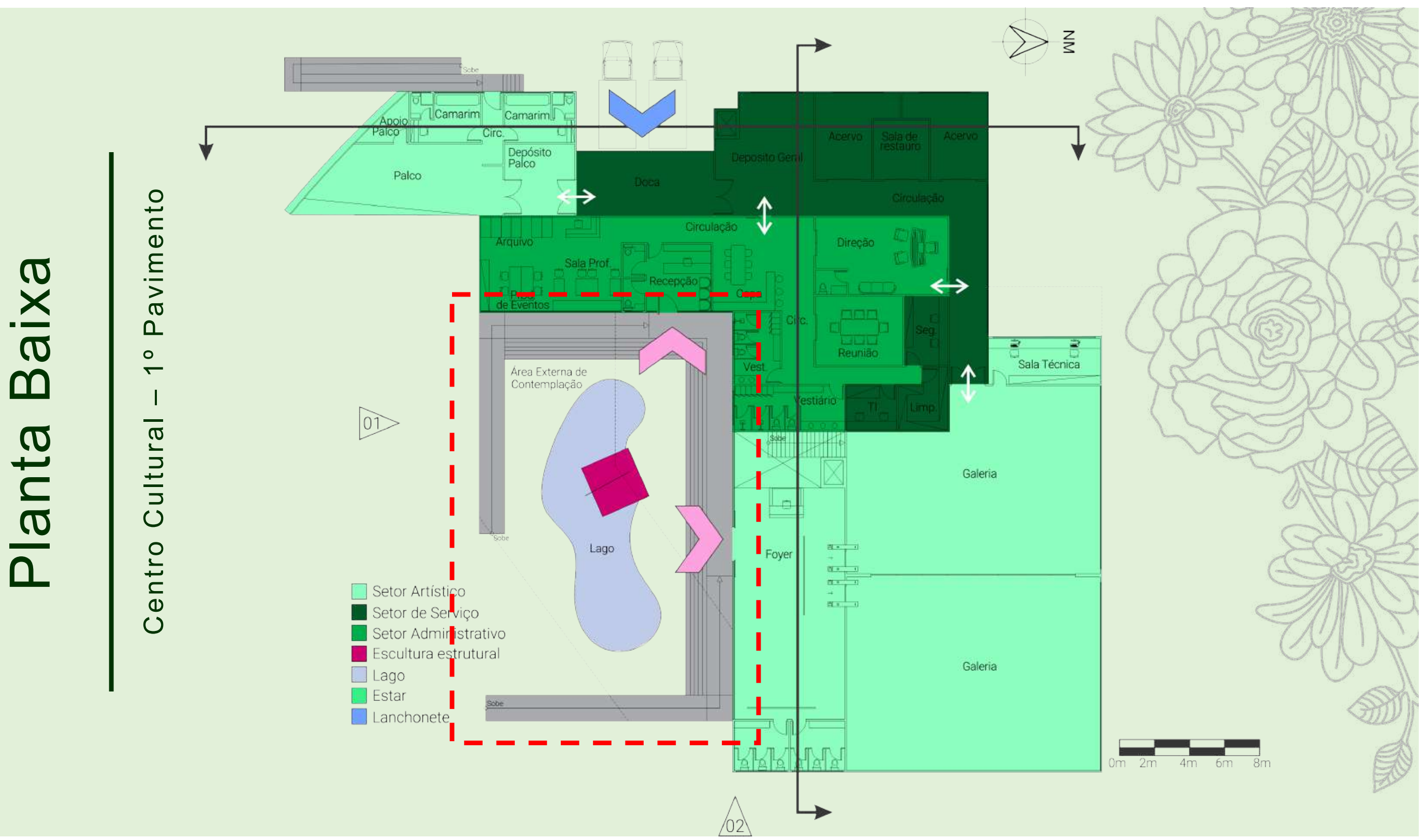



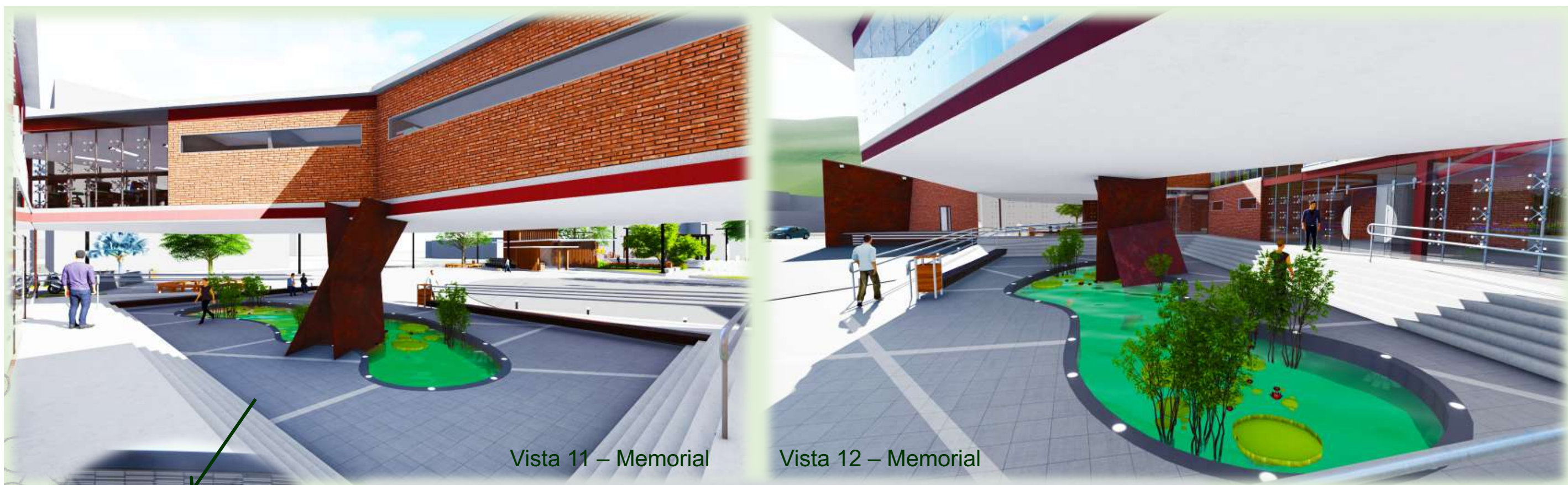

Vista 13 - Memorial

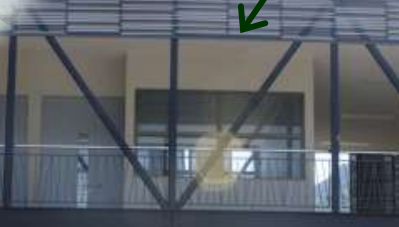

$-y^{2}$

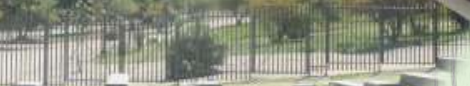

t-an

Centro Cultural el Tranque
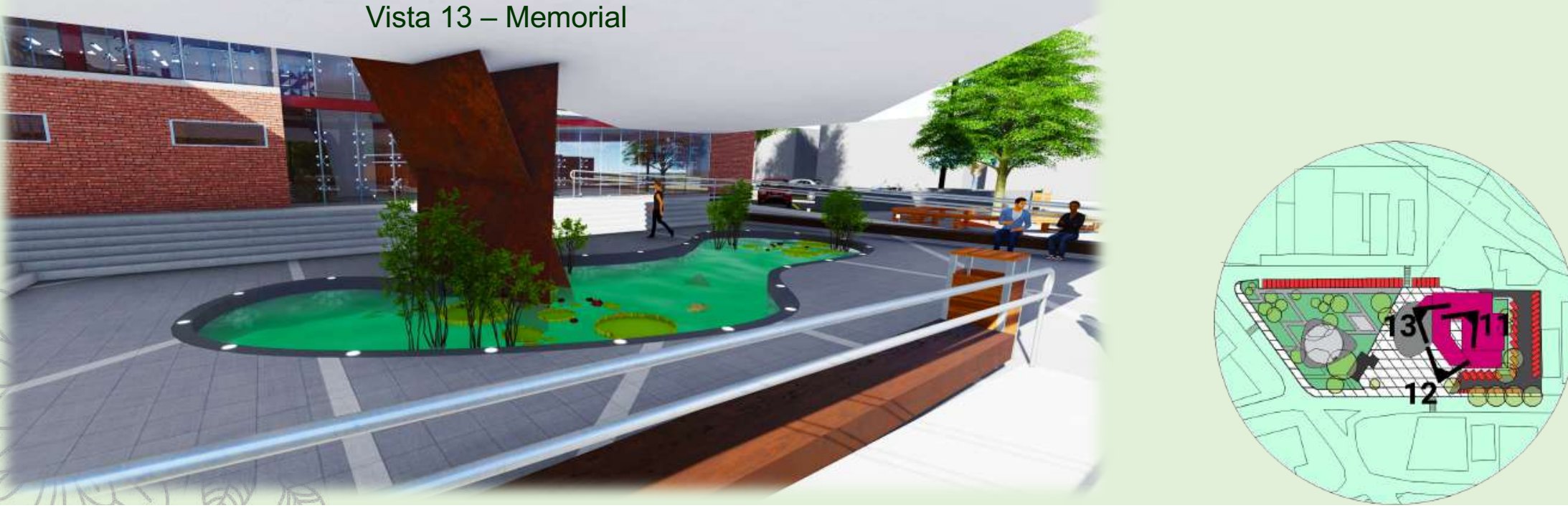


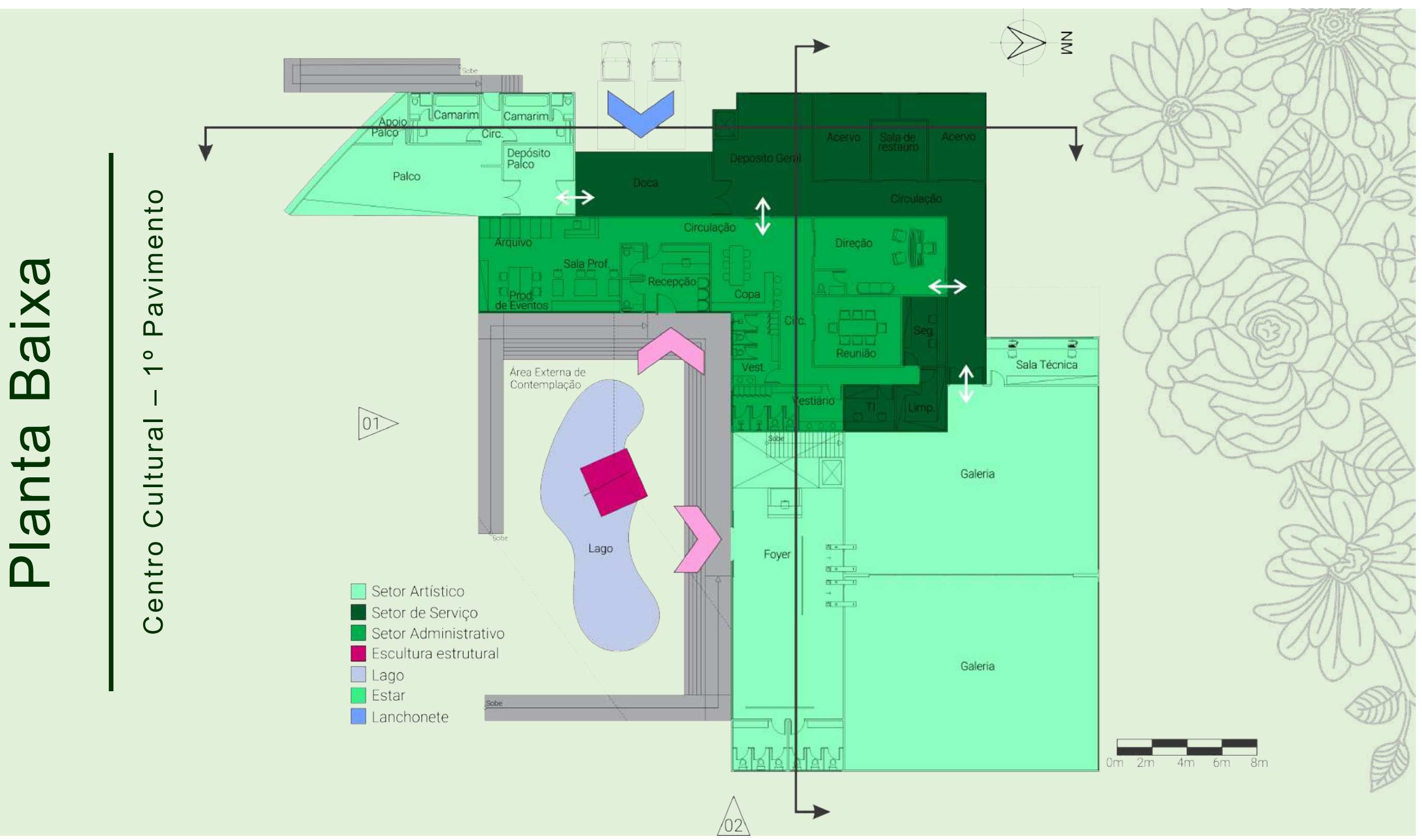




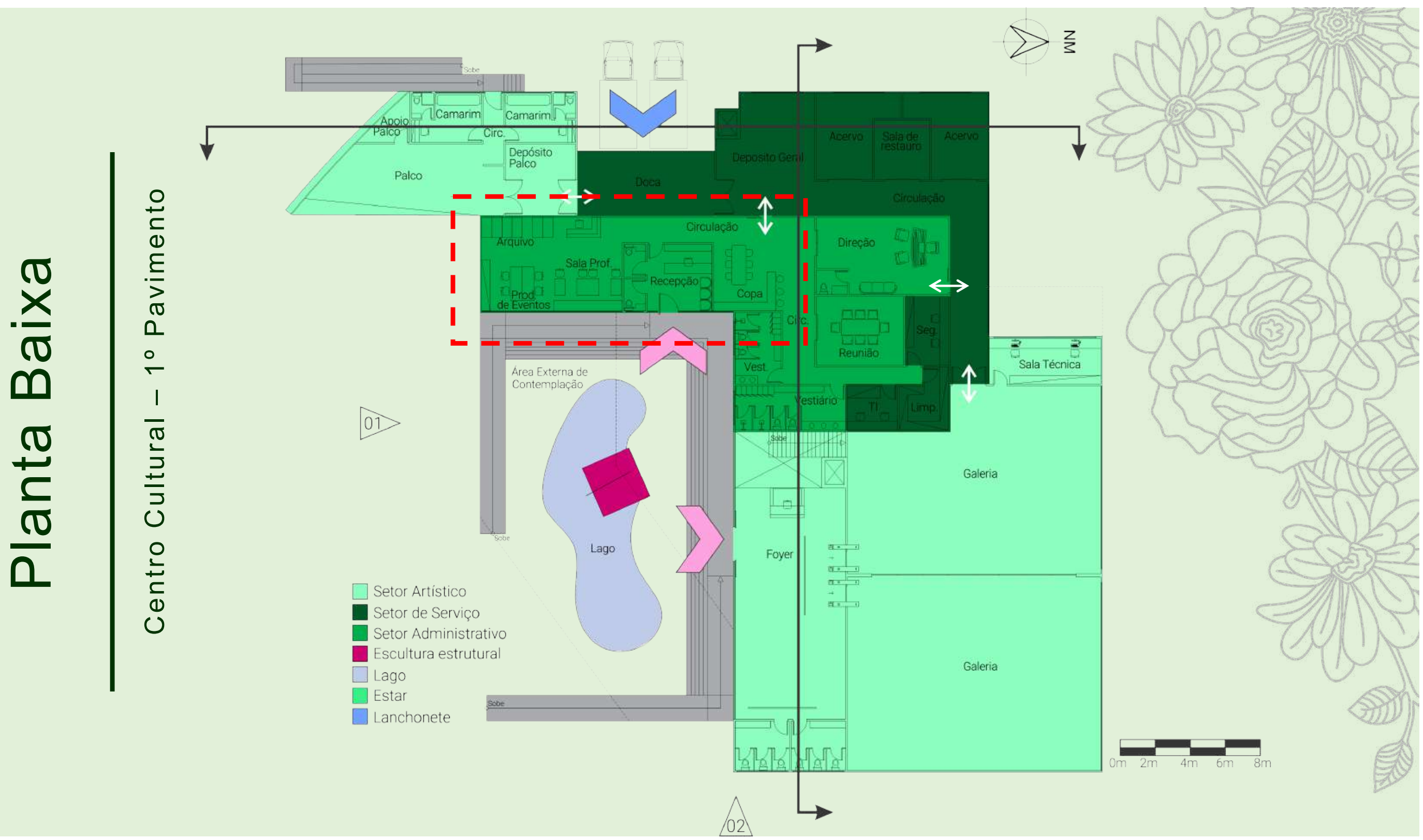




\section{Setor Administrativo}

\section{Circulação}

Arquivo

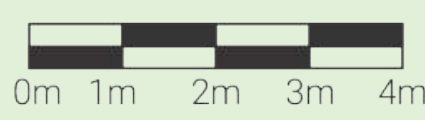



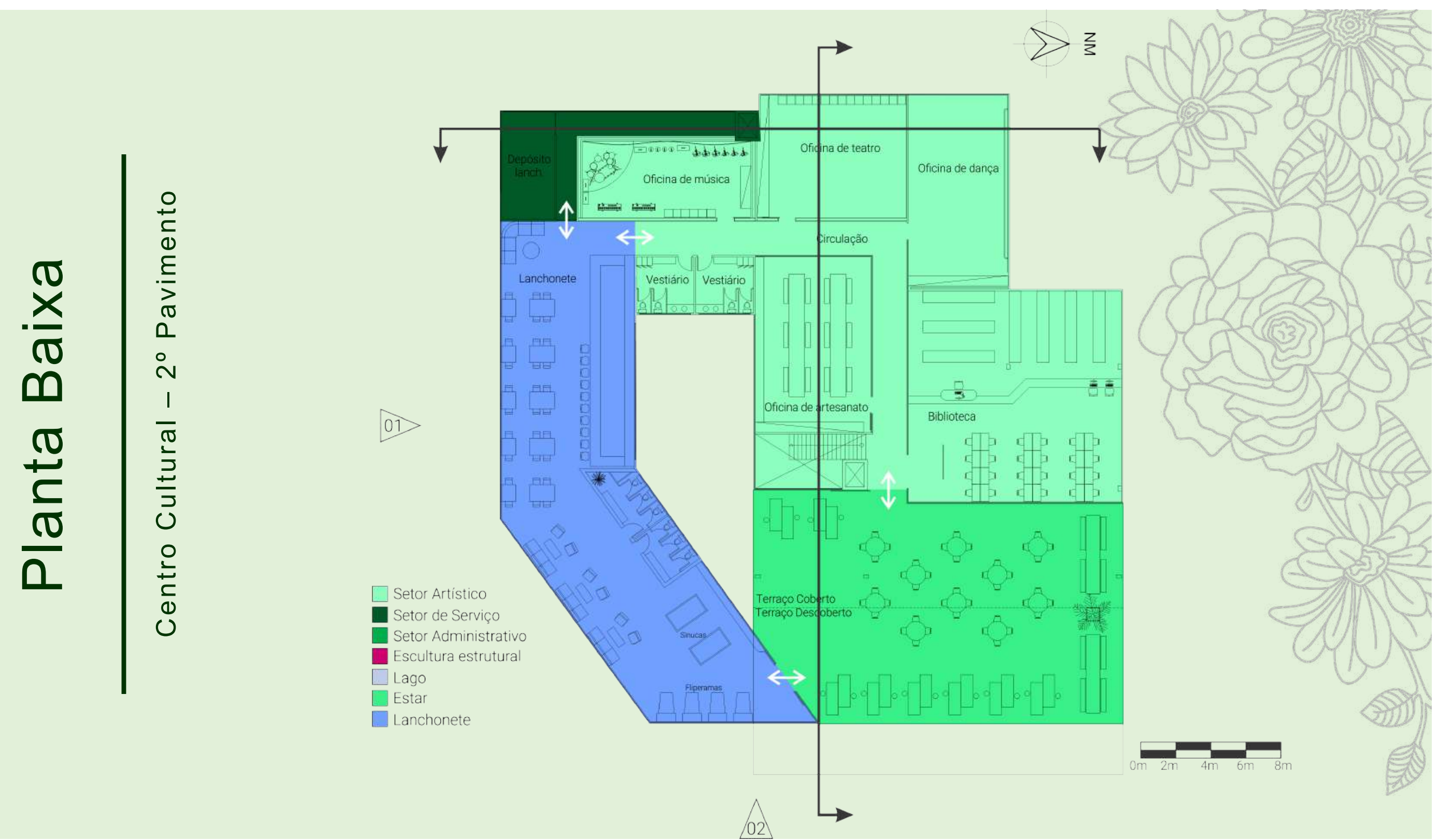


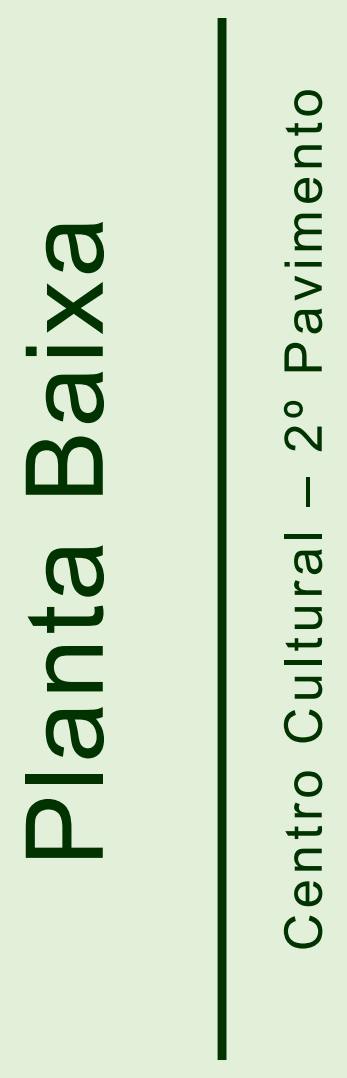

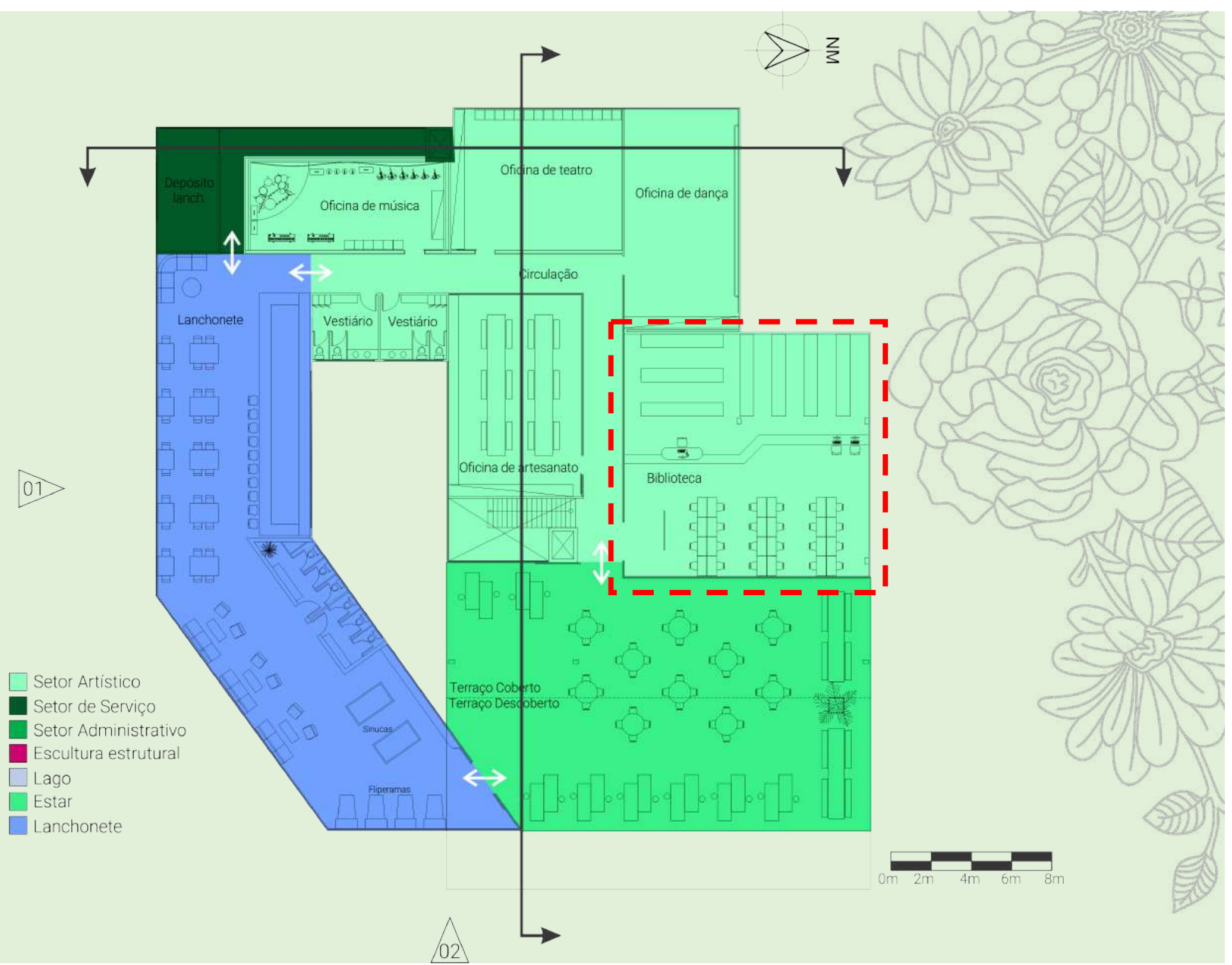



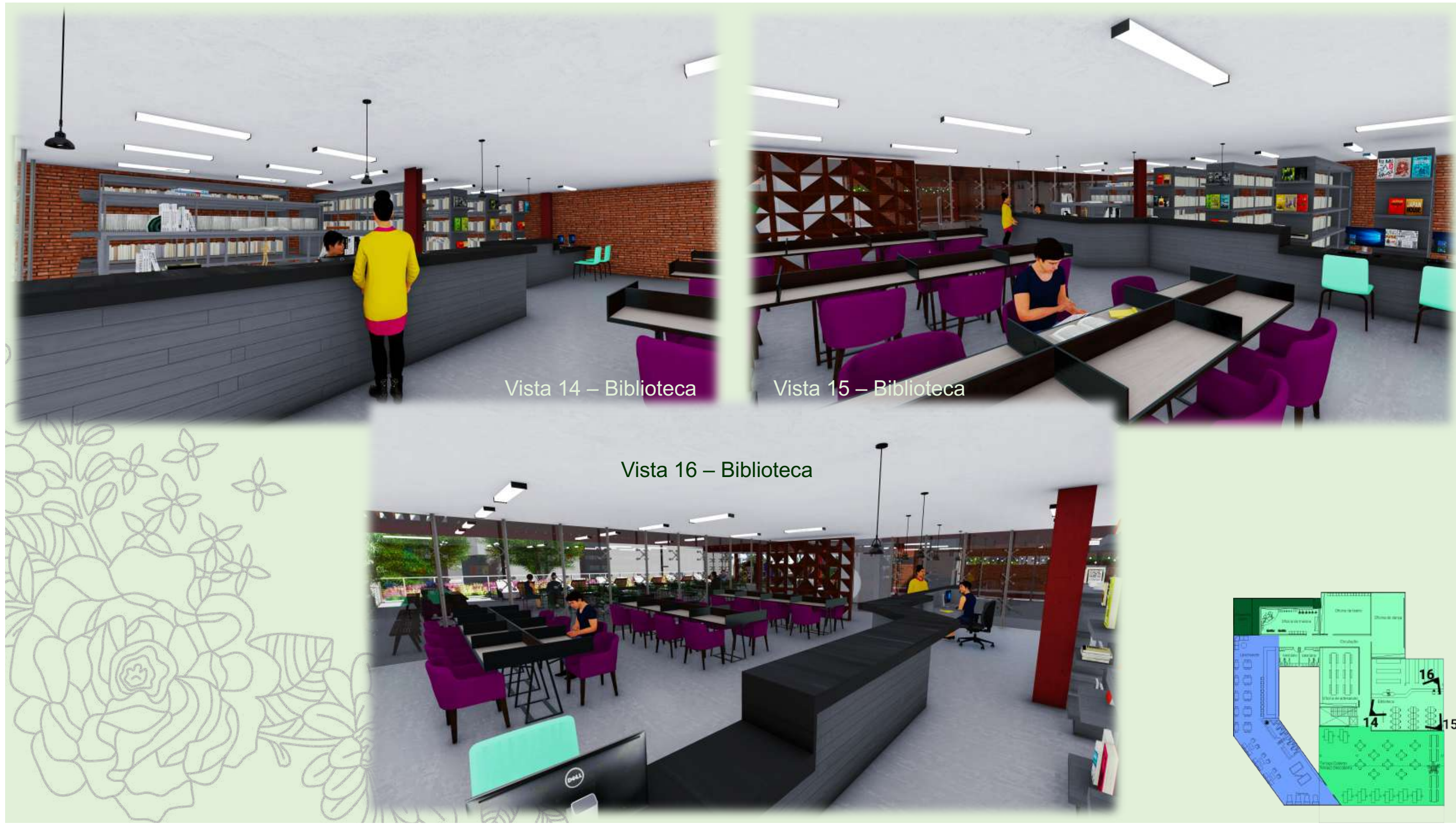


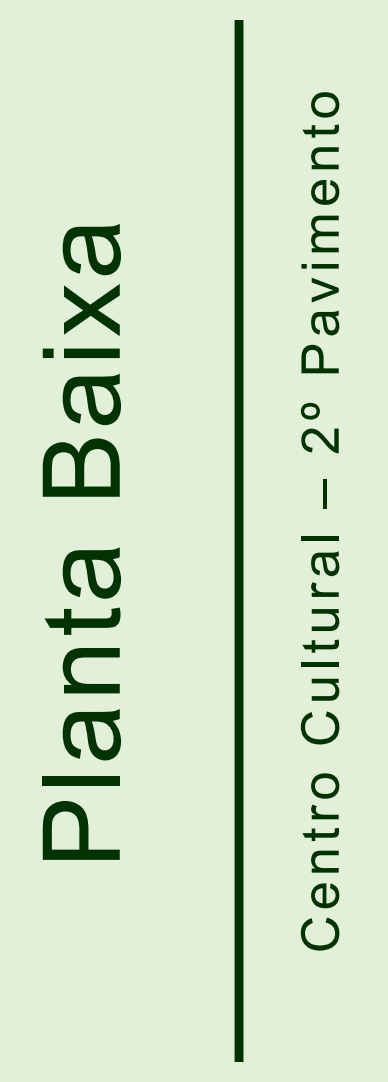

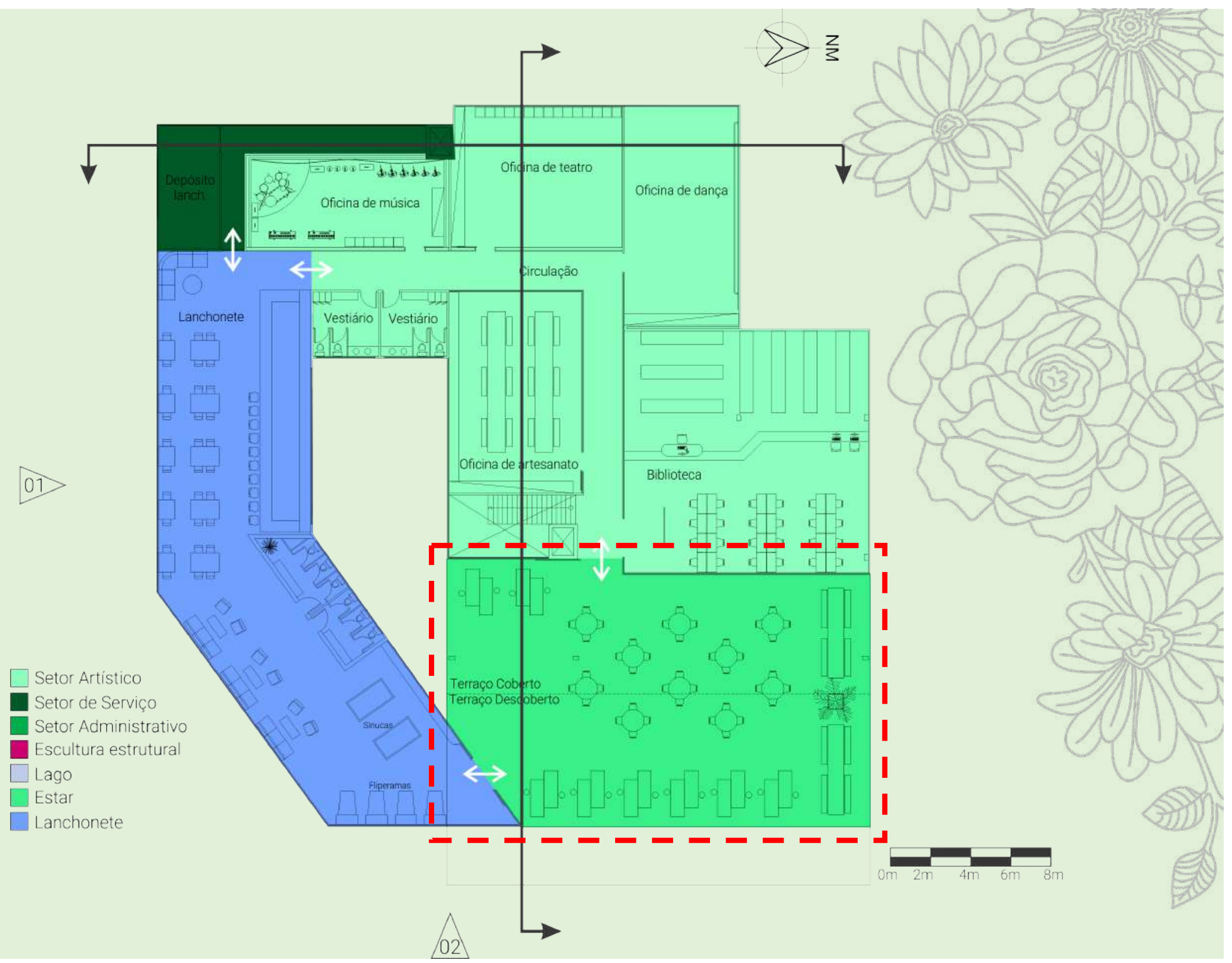



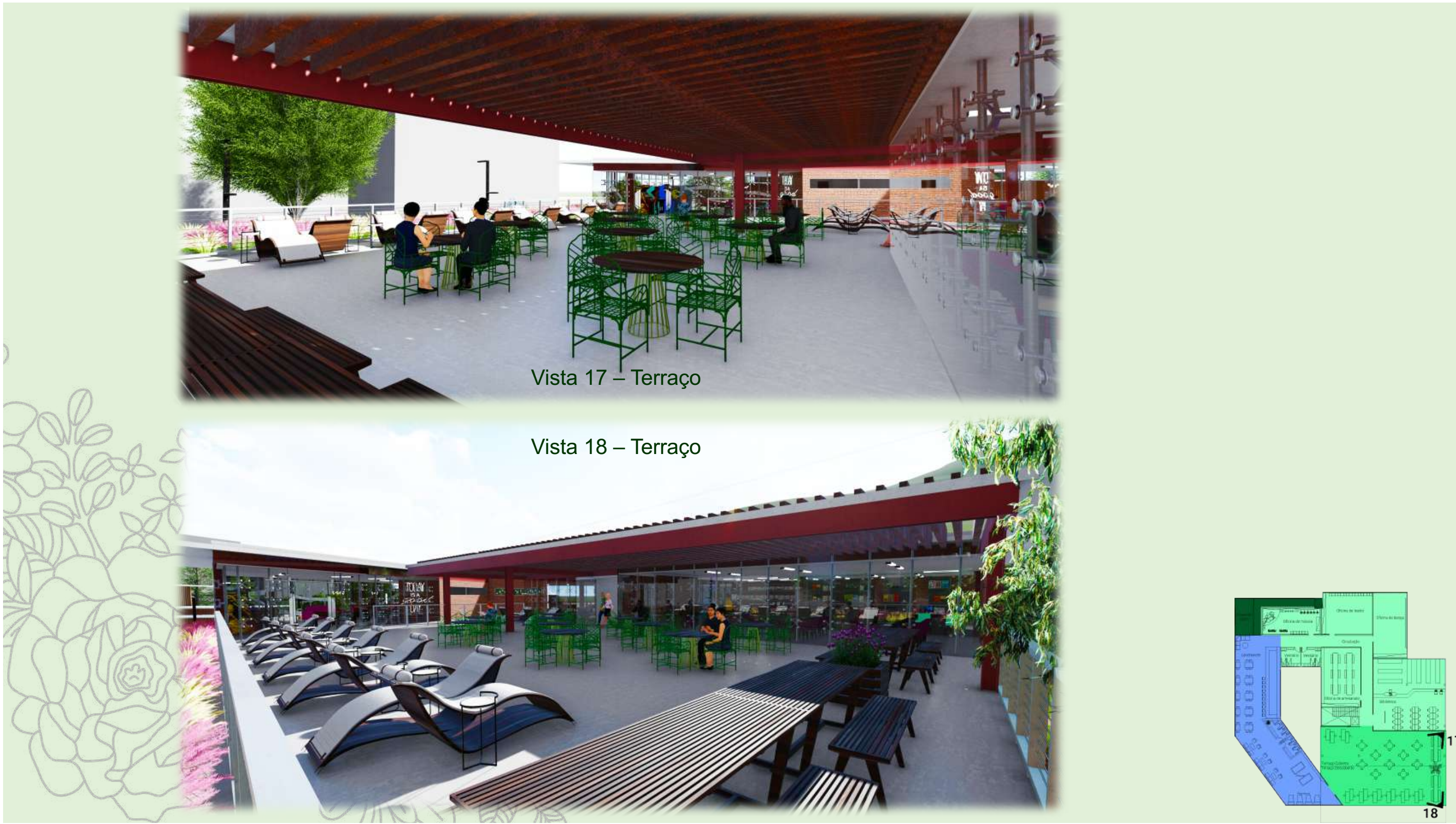

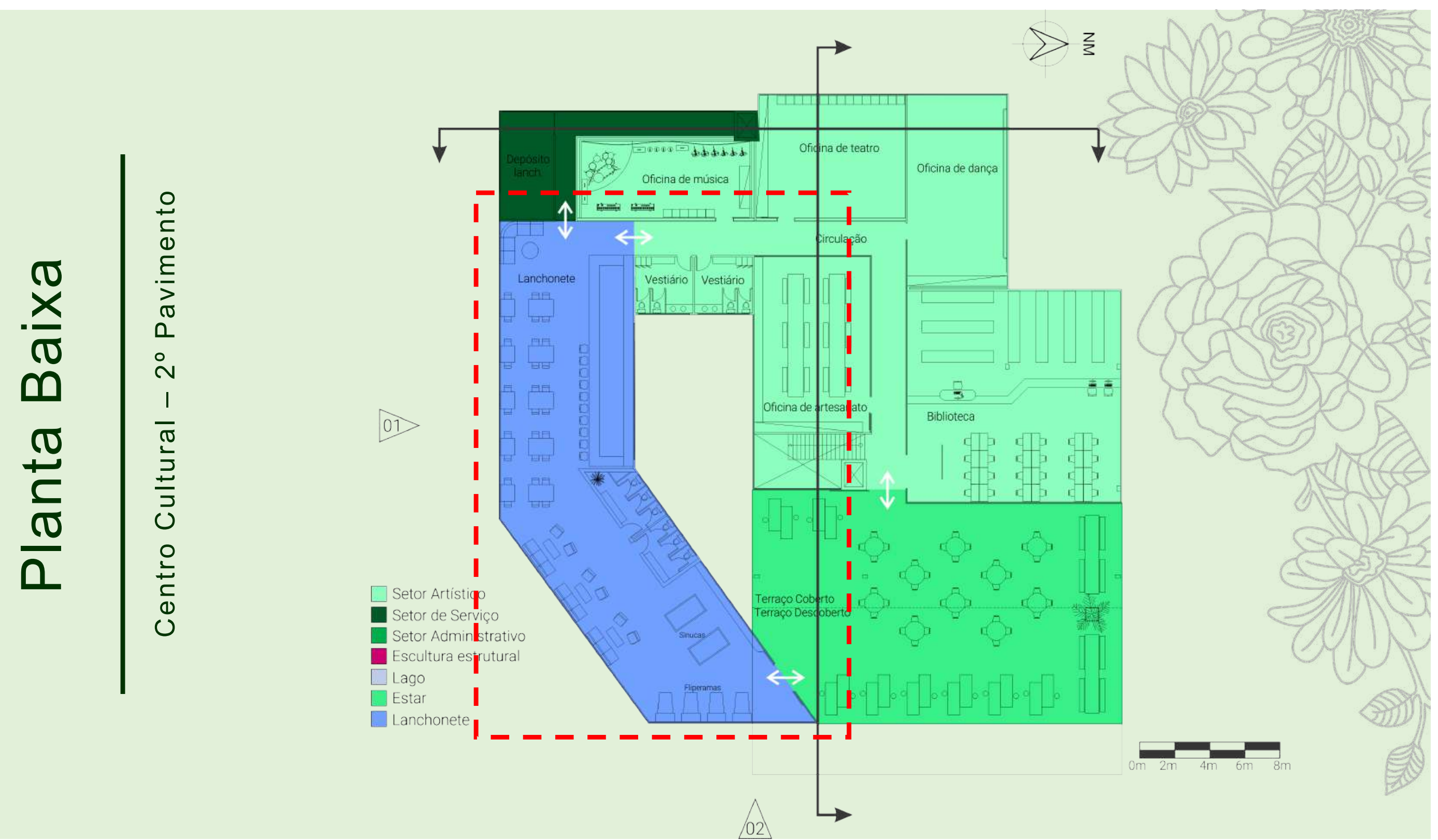


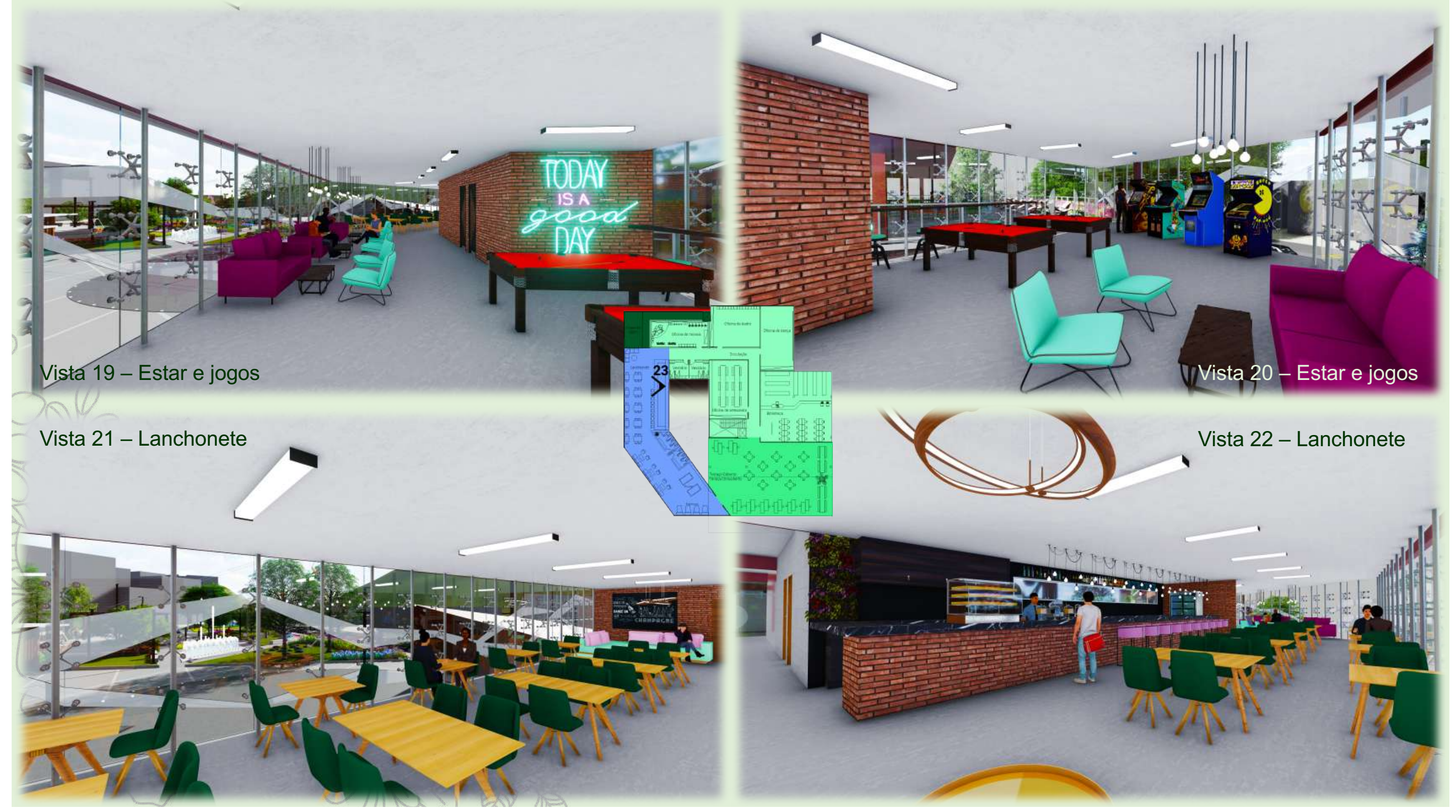




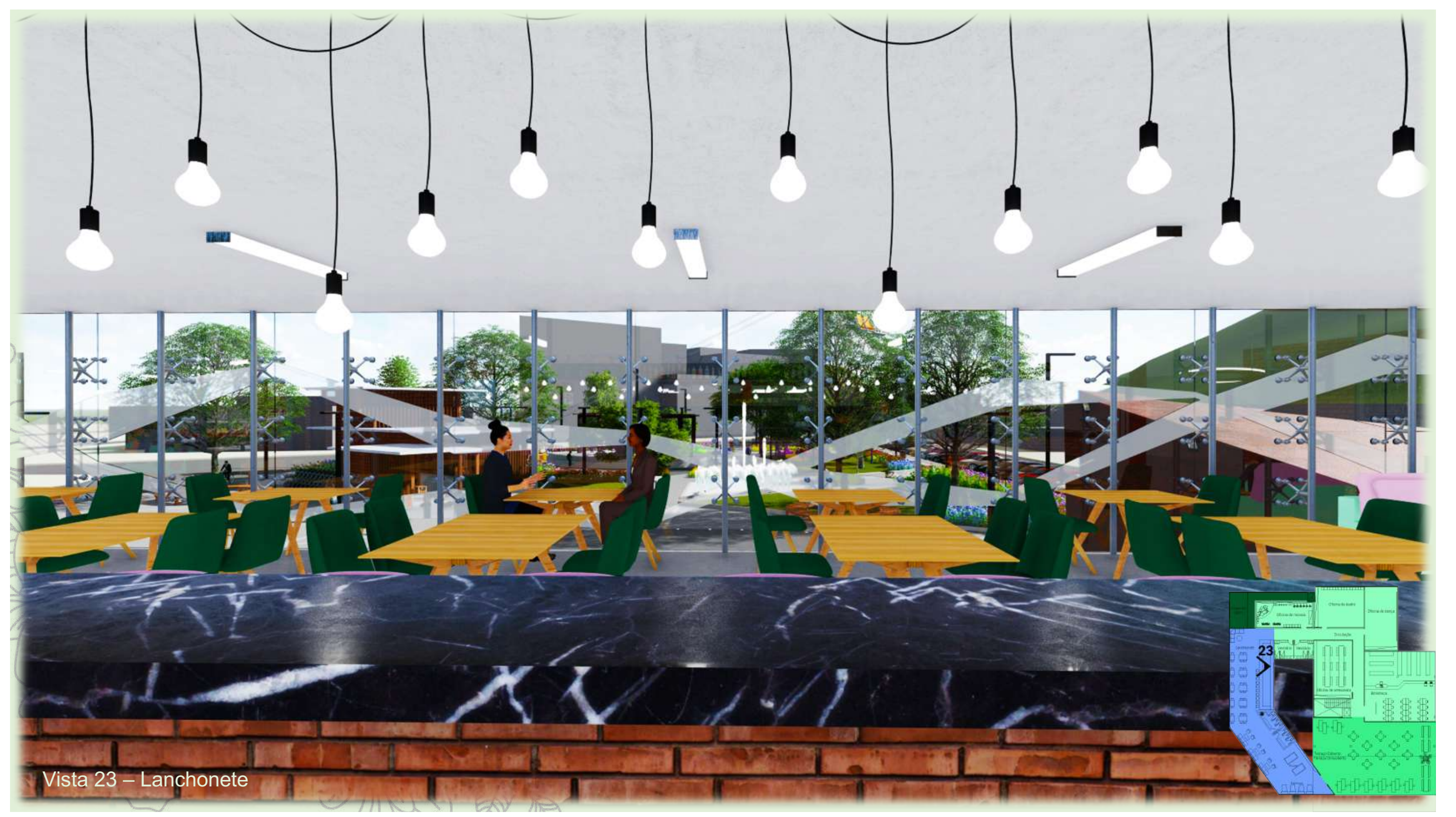




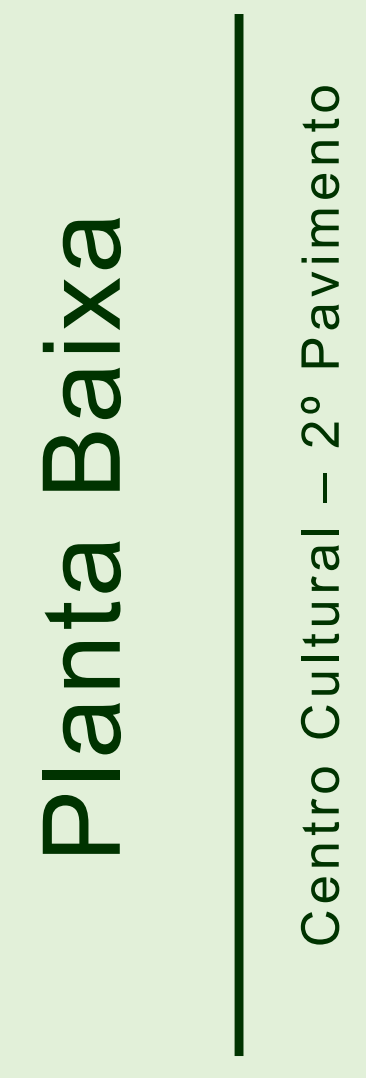

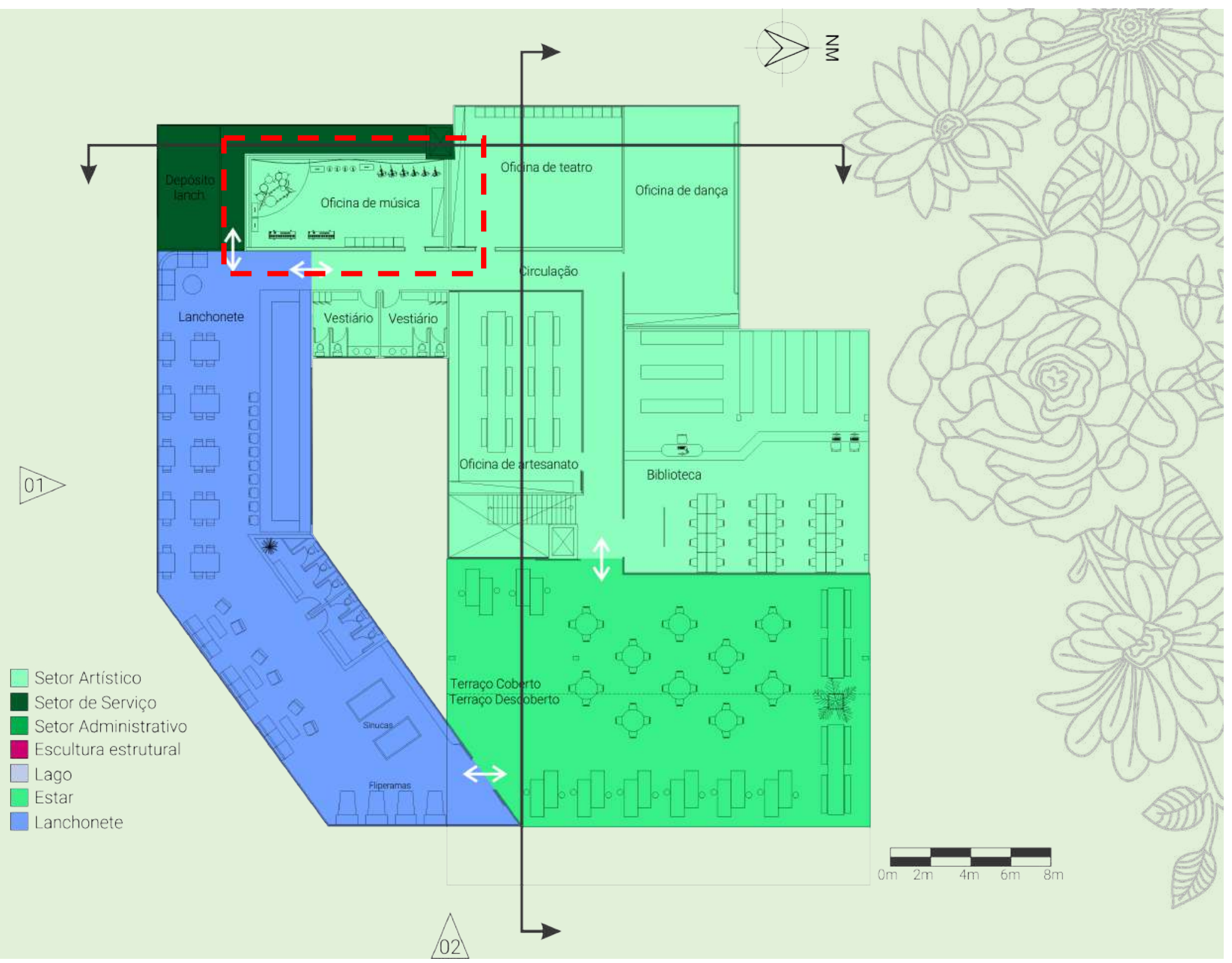




\section{Oficina de Música}

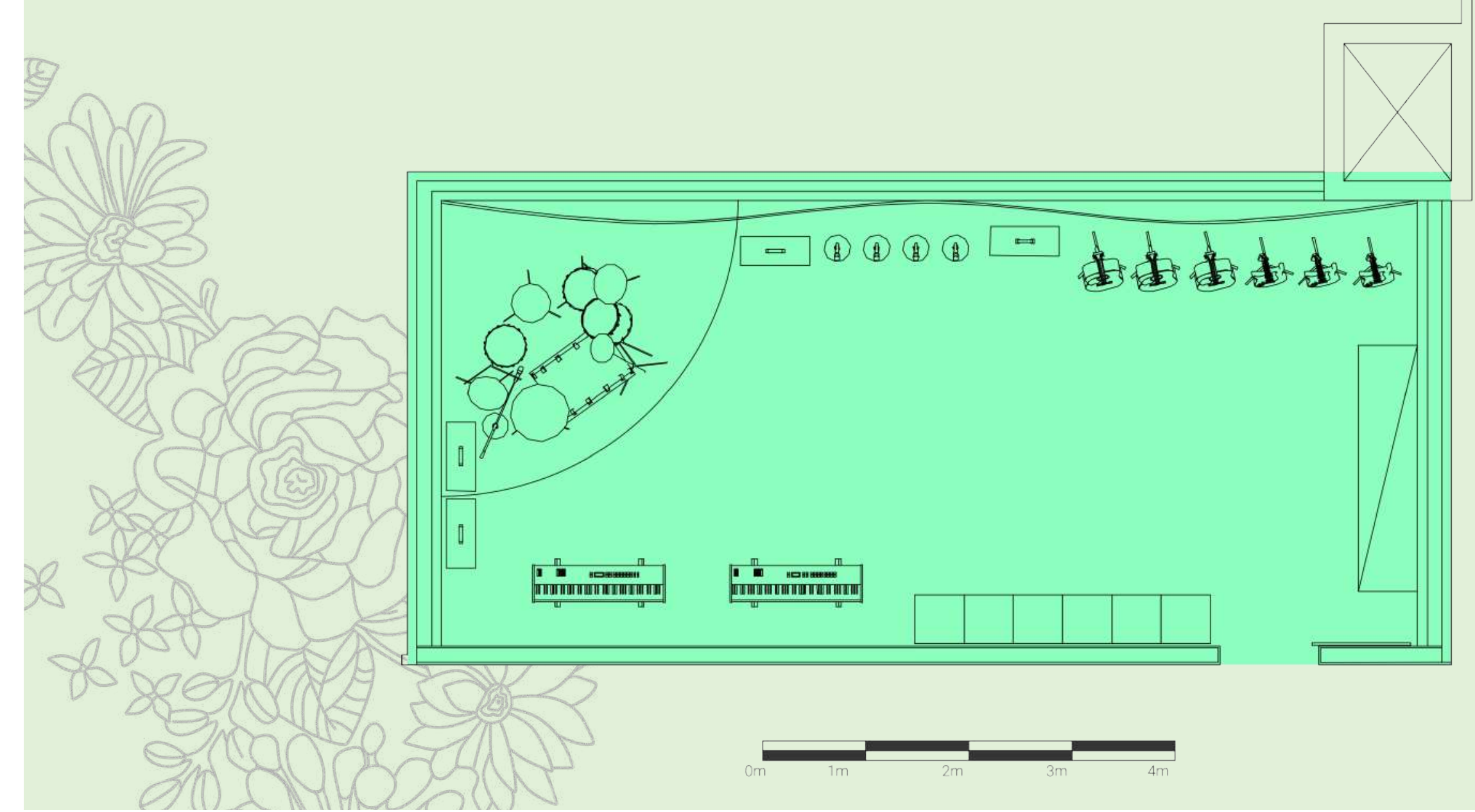




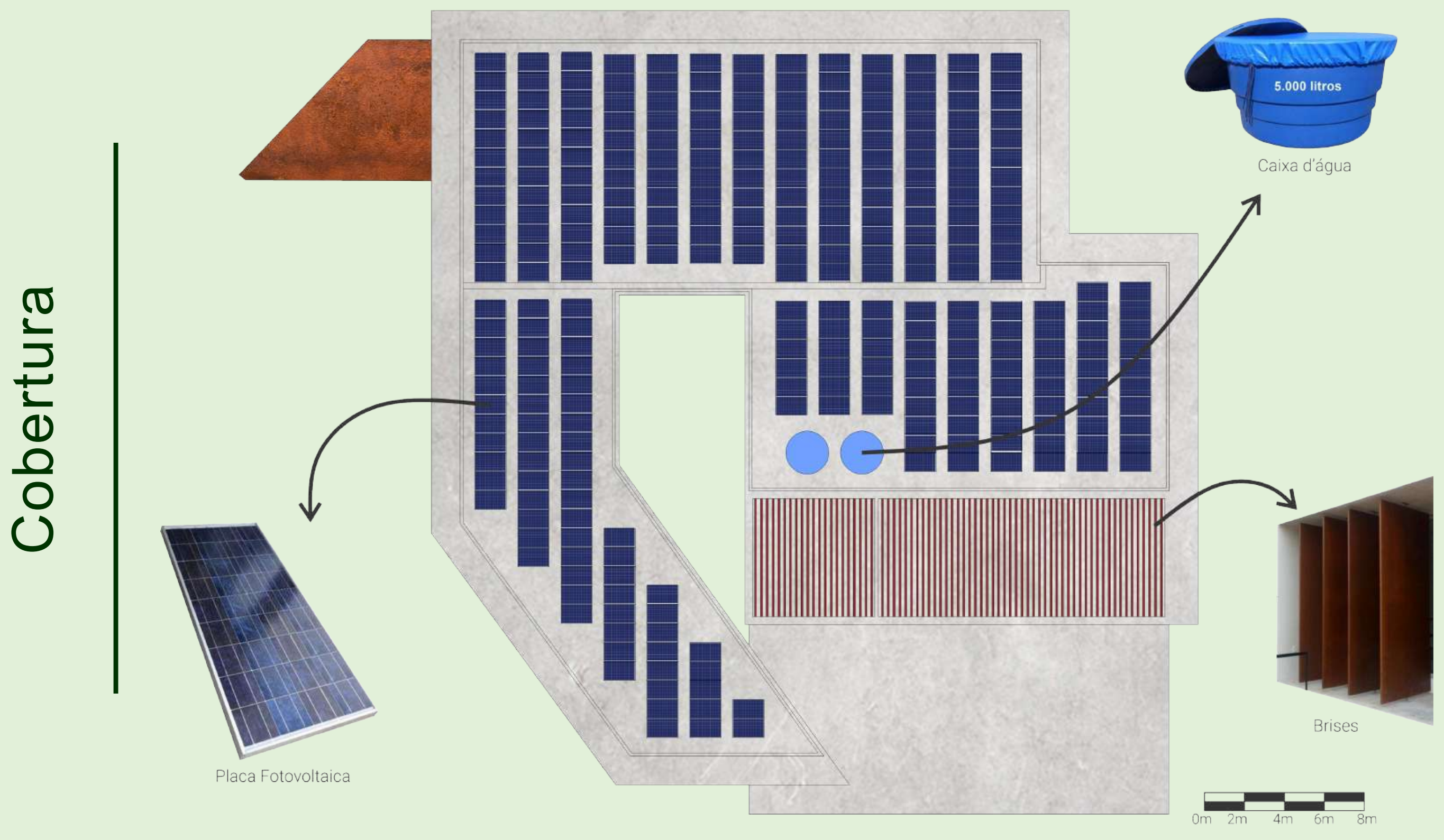




\section{Cortes}

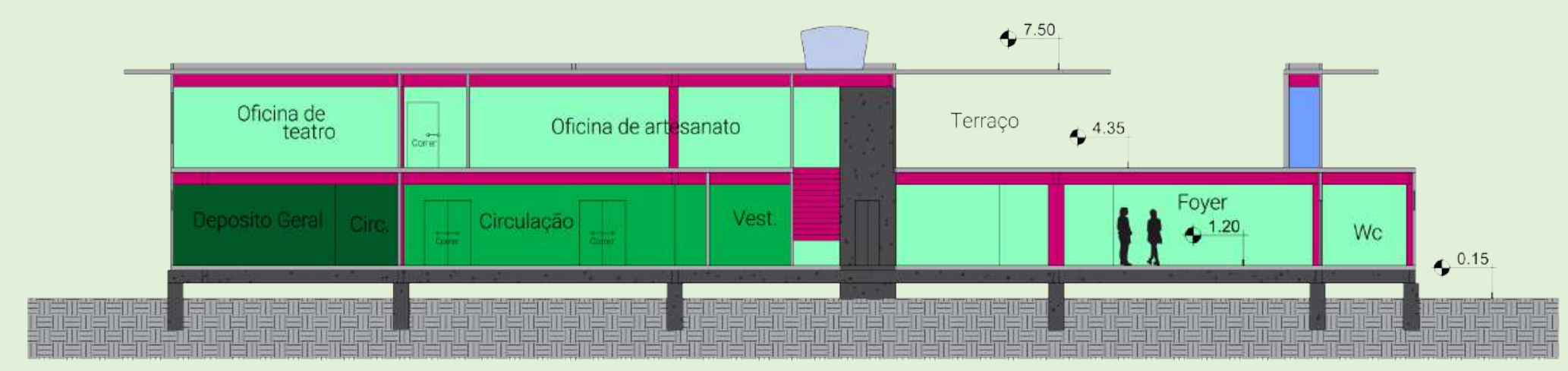

Corte AA

Setor Artístico

- Setor de Serviço

Setor Administrativo

Estrutura Metálica

Estrutura de Concreto

$\square$ Estar

$\square$ Lanchonete

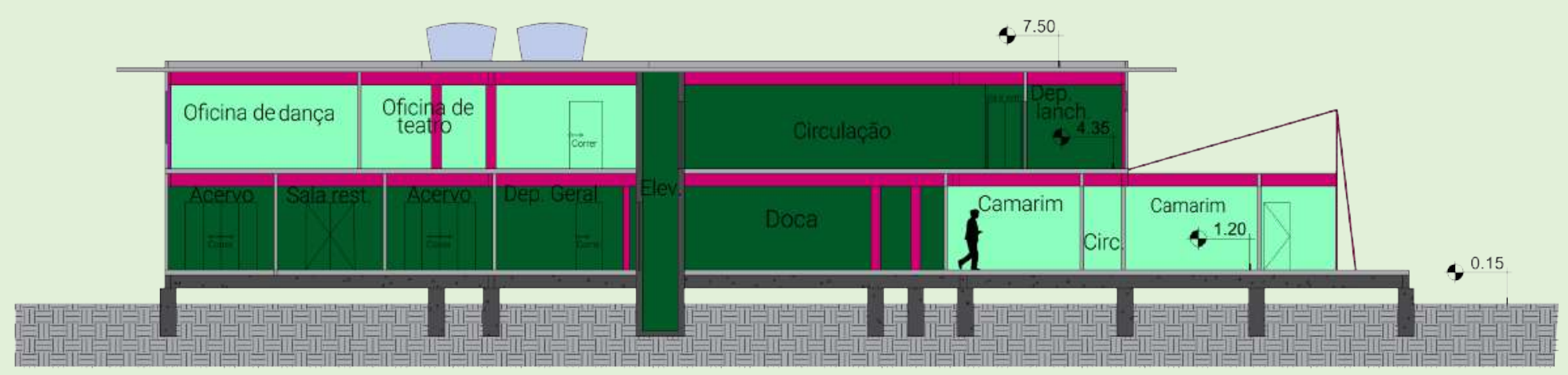

Corte BB

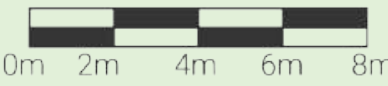




\section{Fachadas}

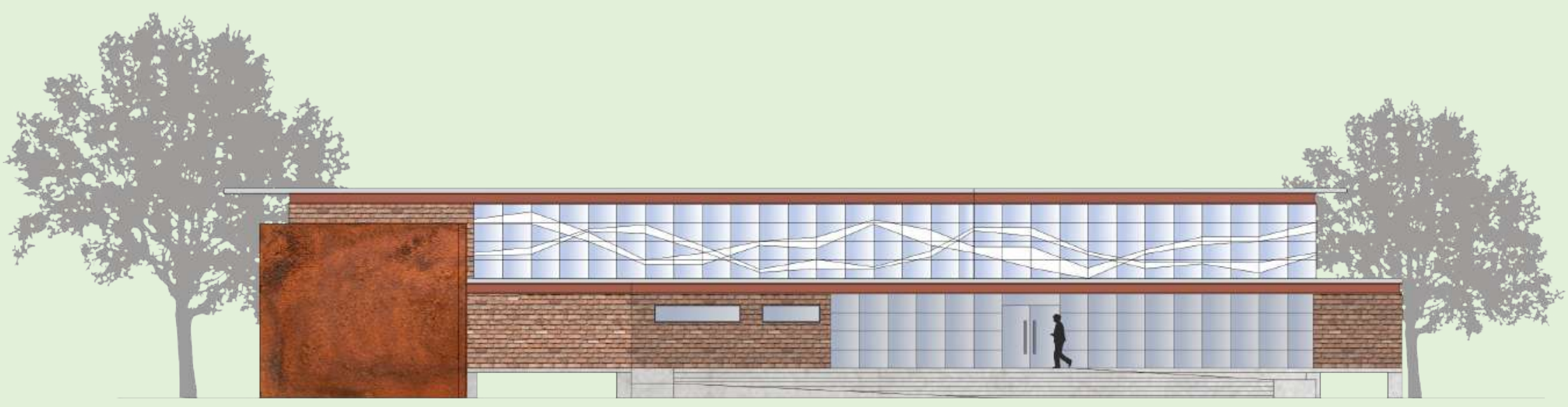

Fachada 01

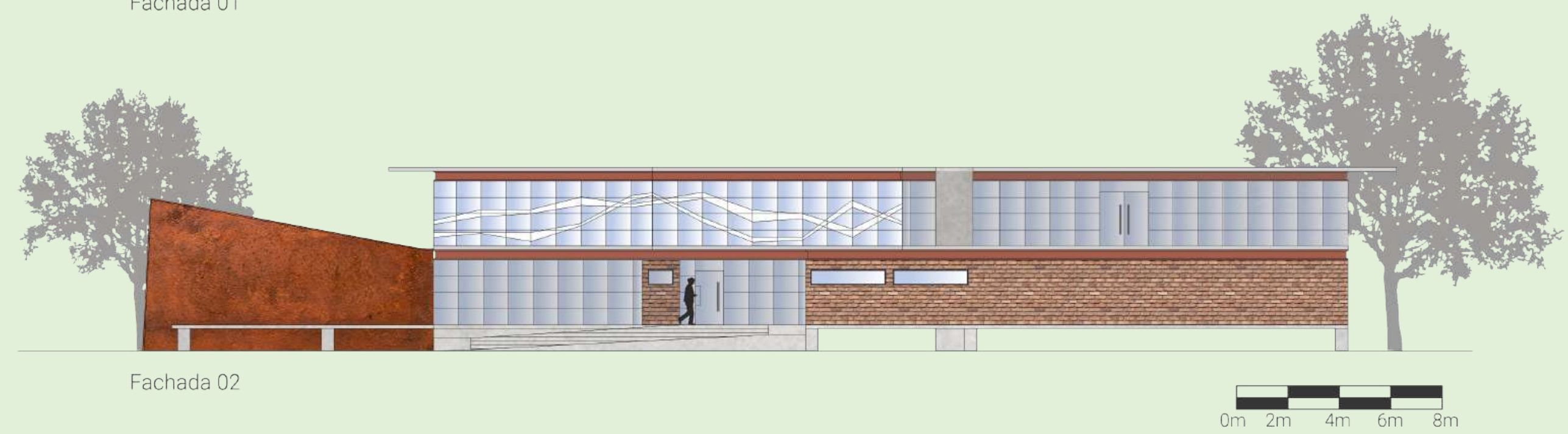




\section{Estratégias Sustentáveis}

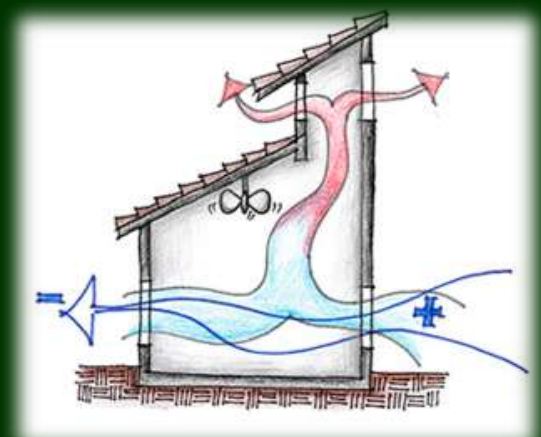

Ventilação natural

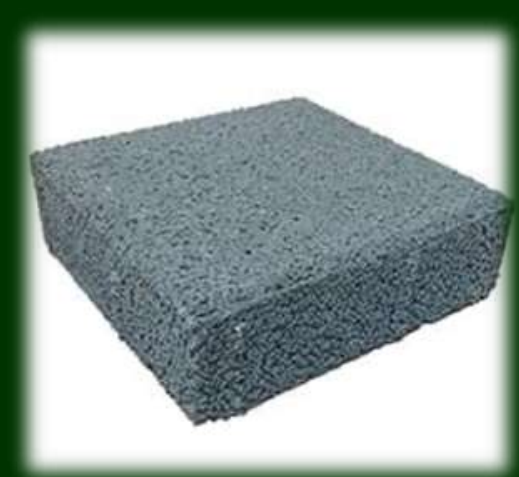

Piso Permeável

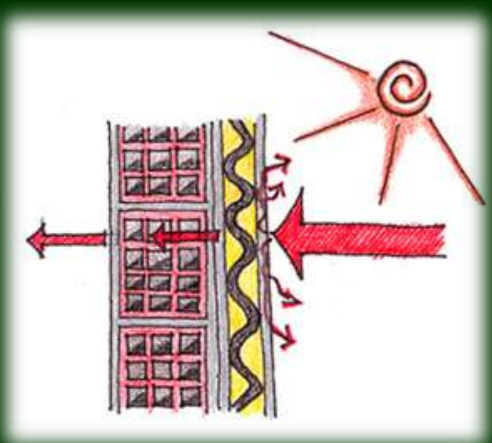

Inércia térmica

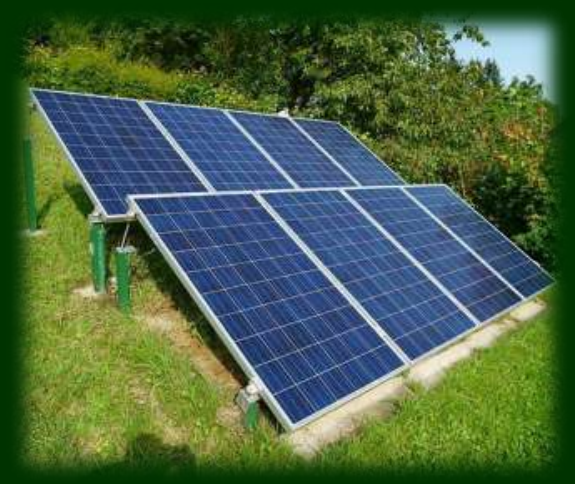

Placa Solar fotovoltaica

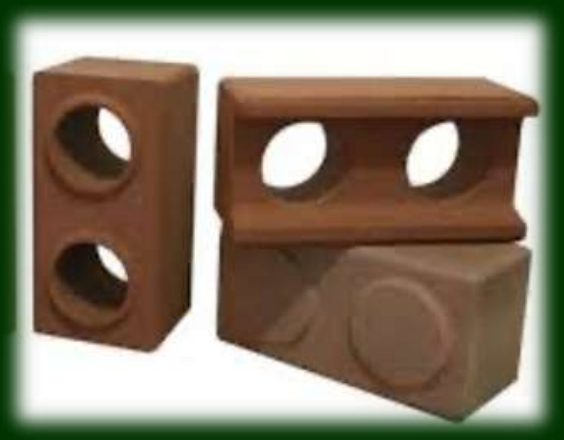

Tijolo solo-cimento

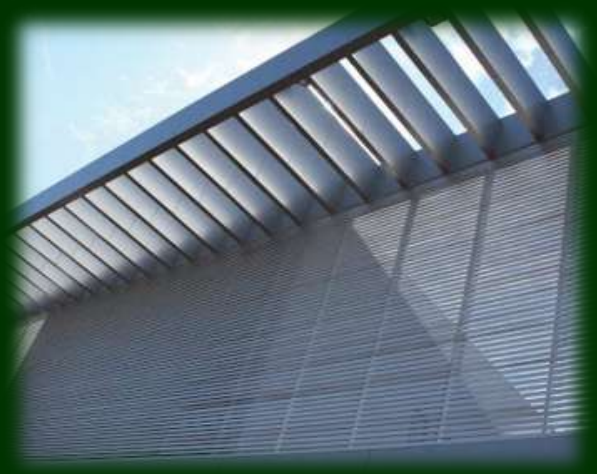

Brises-solei 

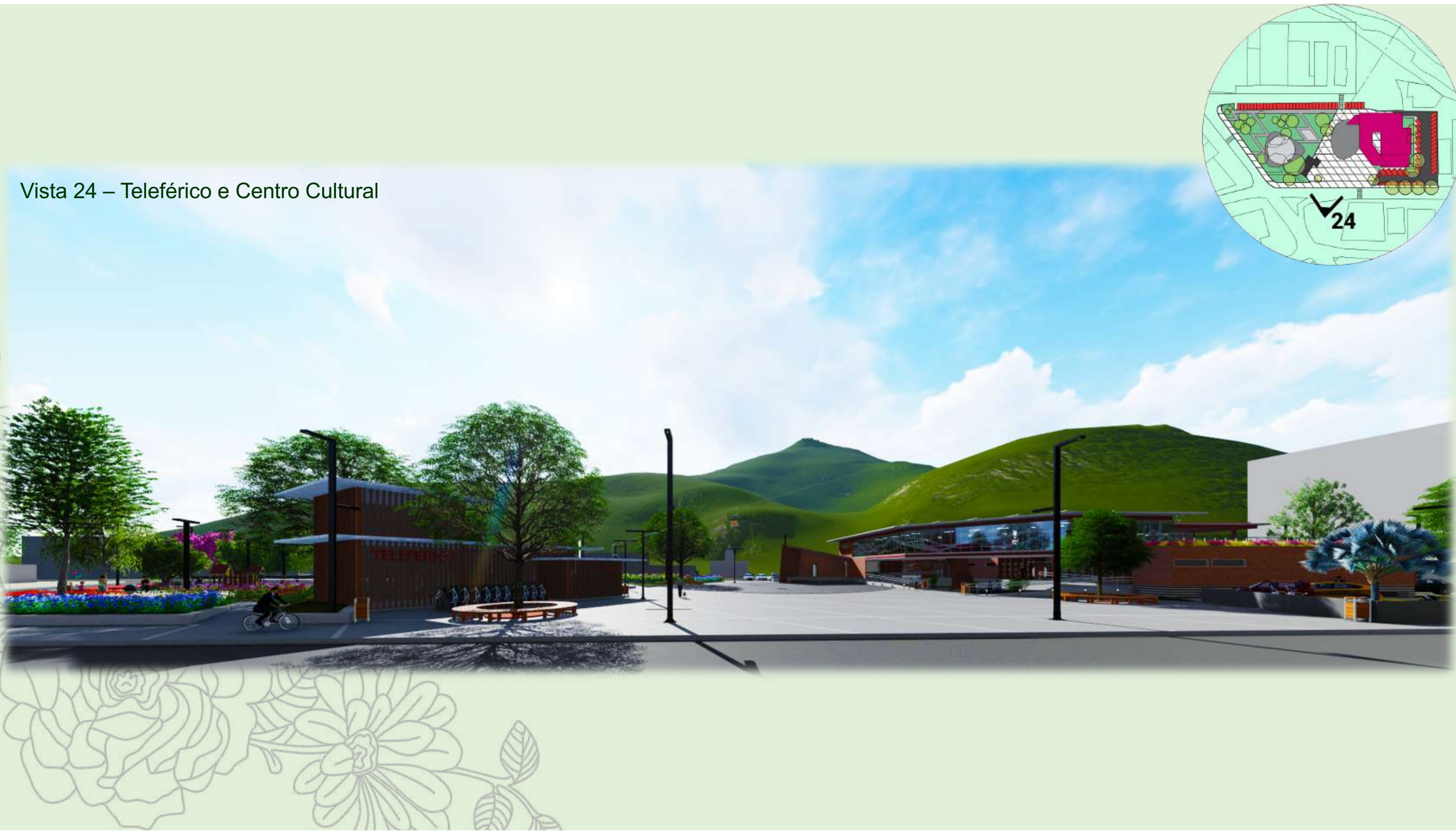

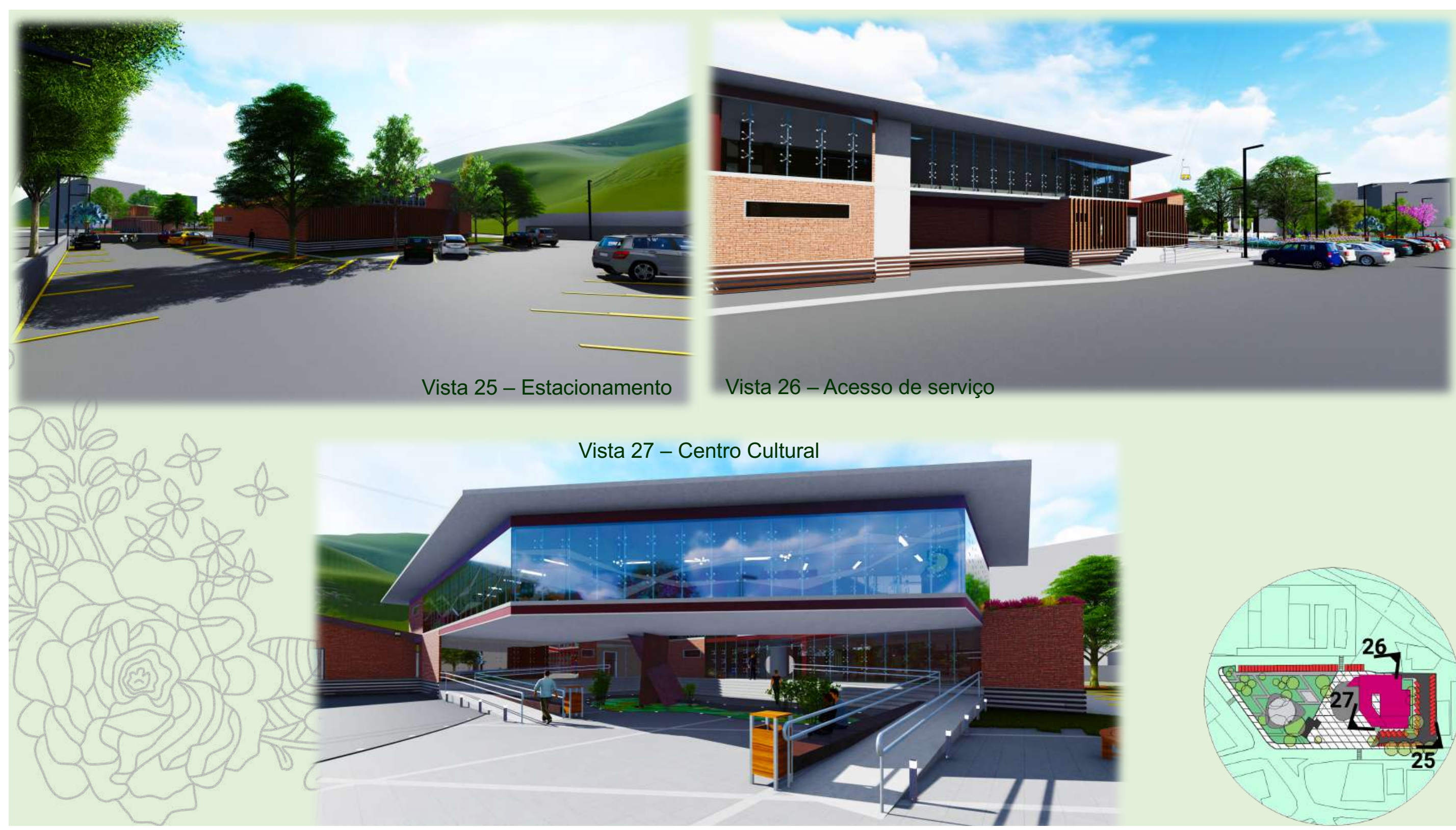


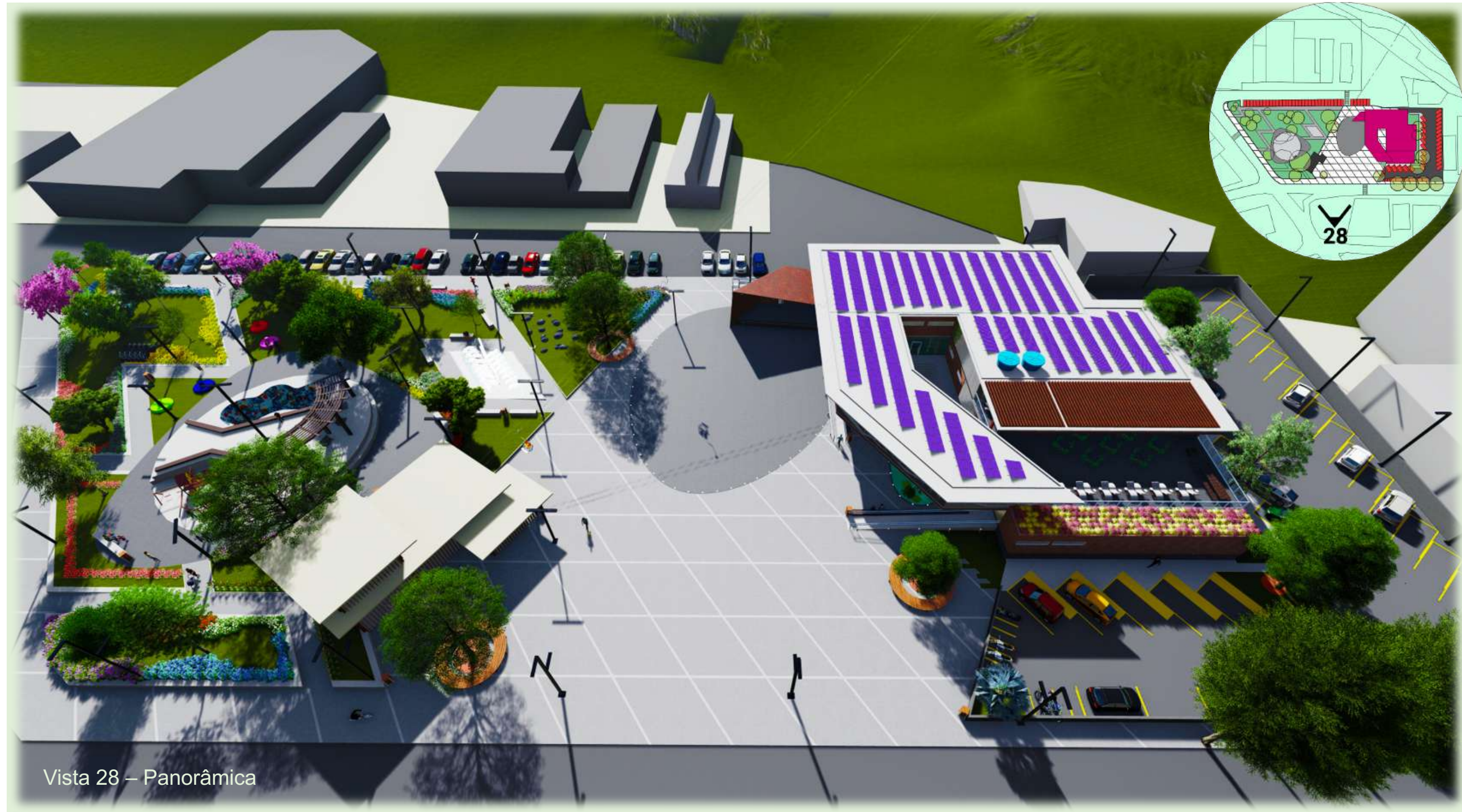

